\title{
Gene Expression Analyses Identify Narp Contribution in the Development of L-DOPA-Induced Dyskinesia
}

\author{
Fanny Charbonnier-Beaupel, ${ }^{1,2,3,4 \star}$ Marion Malerbi, ${ }^{1,2,3,5,6 *}$ Cristina Alcacer, ${ }^{1,5,6 *}$-Khadija Tahiri, ${ }^{1,2,3}$ \\ Wassila Carpentier, ${ }^{7}$ CChuansong Wang, ${ }^{8}$ Matthew During, ${ }^{8}$ Desheng Xu, ${ }^{9}$ Paul F. Worley, ${ }^{9}$ Jean-Antoine Girault, ${ }^{1,5,6}$ \\ Denis Hervé, ${ }^{1,5,6 *}$ and Jean-Christophe Corvol ${ }^{1,2,3,10 *}$ \\ ${ }^{1}$ Sorbonne Universités, UPMC Univ Paris 06, Paris, France, ${ }^{2}$ Inserm, UMR-S 1127, ICM, Pitié-Salpêtrière Hospital, 75013 Paris, France, ${ }^{3} \mathrm{CNRS}$, UMR 7225 , \\ 75013 Paris, France, ${ }^{4}$ Assistance Publique Hôpitaux de Paris, Department of Pharmacy, Pitié-Salpêtrière Hospital, 75013 Paris, France, ${ }^{5}$ Inserm UMR-S 839 , \\ 75005 Paris, France, ${ }^{6}$ Institut du Fer à Moulin, 75005 Paris, France, ${ }^{7}$ UPMC Univ Paris 06, Post genomic platform P3S, 75013 Paris, France, ${ }^{8}$ Departments of \\ Molecular Virology, Immunology and Medical Genetics, Neuroscience and Neurological Surgery, The Ohio State University, Columbus, Ohio 43210, ${ }^{9} \mathrm{Johns}$ \\ Hopkins University School of Medicine, Solomon H. Snyder Department of Neuroscience, Baltimore, Maryland 21205, and ${ }^{10}$ Assistance Publique Hôpitaux \\ de Paris, Inserm, Clinical Investigation Center, CIC-1422, Pitié-Salpêtrière Hospital, 75013 Paris, France
}

In Parkinson's disease, long-term dopamine replacement therapy is complicated by the appearance of L-DOPA-induced dyskinesia (LID). One major hypothesis is that LID results from an aberrant transcriptional program in striatal neurons induced by L-DOPA and triggered by the activation of ERK. To identify these genes, we performed transcriptome analyses in the striatum in 6-hydroxydopamine-lesioned mice. A time course analysis ( $0-6 \mathrm{~h}$ after treatment with L-DOPA) identified an acute signature of 709 genes, among which genes involved in protein phosphatase activity were overrepresented, suggesting a negative feedback on ERK activation by L-DOPA. L-DOPA-dependent deregulation of 28 genes was blocked by pretreatment with SL327, an inhibitor of ERK activation, and 26 genes were found differentially expressed between highly and weakly dyskinetic animals after treatment with L-DOPA. The intersection list identified five genes: Fos $B, T h, N p t x 2$, Nedd4l, and Ccrn4l. Nptx2 encodes neuronal pentraxin II (or neuronal activity-regulated pentraxin, Narp), which is involved in the clustering of glutamate receptors. We confirmed increased Nptx2 expression after L-DOPA and its blockade by SL327 using quantitative RT-PCR in independent experiments. Using an escalating L-DOPA dose protocol, LID severity was decreased in Narp knock-out mice compared with their wild-type littermates or after overexpression of a dominant-negative form of Narp in the striatum. In conclusion, we have identified a molecular signature induced by L-DOPA in the dopamine-denervated striatum that is dependent on ERK and associated with LID. Here, we demonstrate the implication of one of these genes, $N p t x 2$, in the development of LID.

Key words: L-DOPA-induced dyskinesia; Narp; Parkinson's disease; transcriptome

\section{Introduction}

In Parkinson's disease (PD), motor symptoms are mainly caused by degeneration of dopaminergic neurons from the substantia nigra pars compacta projecting to the dorsal striatum. Although

\footnotetext{
Received Dec. 8, 2013; revised Nov. 1, 2014; accepted Nov. 5, 2014.

Author contributions: F.C.-B., M.M., C.A., J.-A.G., D.H., and J.-C.C. designed research; F.C.-B., M.M., C.A., K.T., W.C., C.W., M.D., D.X., D.H., and J.-C.C. performed research;P.F.W. contributed unpublished reagents/analytic tools; F.C.-B., M.M., K.T., and J.-C.C. analyzed data; F.C.-B., M.M., C.A., K.T., W.C., C.W., M.D., D.X., P.F.W., J.-A.G., D.H., and J.-C.C. wrote the paper.

The work was supported by the University Pierre and Marie Curie (UPMC), Inserm (Grant Inserm/DHOS2008), the Fondation pour la Recherche Médicale, the Société française de pharmacologie et de thérapeutique, the Agence Nationale de la Recherche (Grant ANR09-MNPS-014), the Michael Stern Parkinson's Research Foundation, and the European Research Council. The research leading to these results has received funding from the program "Investissements d'avenir" ANR-10-IAIHU-06. P.W. was supported by National Institutes of Health Grant R01 NS039156.; We thank the staff of the Institut du Fer a Moulin Imaging and animal facilities and the staff of the Plateforme post-genomique P3S facility at the Pitié-Salpêtrière Hospital. Analyses were performed using Biometric Research Branch ArrayTools developed by Dr. Richard Simon and BRB-ArrayTools Development Team.

The authors declare no competing financial interests.

*F.C.-B., M.M., C.A., D.H., and J.-C.C. contributed equally to this work.

Correspondence should be addressed to Dr. Jean-Christophe CORVOL, ICM, Hôpital de la Pitié-Salpêtrière, 47 Bd de I'Hôpital, 75651 Paris Cedex 13, France. E-mail: jean-christophe.corvol@psl.aphp.fr.

DOI:10.1523/JNEUROSCI.5231-13.2015

Copyright $\odot 2015$ the authors $\quad 0270-6474 / 15 / 350096-16 \$ 15.00 / 0$
}

dopamine replacement therapy by L-DOPA remains the most widely used treatment of motor symptoms, it is complicated by the development of abnormal involuntary movements (AIMs) called L-DOPA-induced dyskinesia (LID; Duvoisin, 1974). Converging evidence suggests that LID results from aberrant neuroplasticity triggered by the repeated stimulation of "sensitized" dopamine receptors (Obeso et al., 2000; Jenner, 2008).

Dopamine controls long-term potentiation and depression (LTP and LTD) of corticostriatal synapses (Shen et al., 2008) in medium-sized spiny striatal neurons (MSNs), which express either $\mathrm{D} 1$ or $\mathrm{D} 2$ dopamine receptors (D1R or D2R, respectively; Gerfen et al., 1990). Corticostriatal plasticity is altered in animal models of PD and is rescued by chronic L-DOPA treatment (Calabresi et al., 2007; Kreitzer and Malenka, 2007). Dyskinetic animals selectively display a loss of LTP depotentiation after lowfrequency stimulation of afferents, an effect resulting from D1R signaling sensitization (Picconi et al., 2003). D1R signaling is enhanced in the striatum after dopamine denervation in animal models and in patients with PD (Hervé et al., 1993; Corvol et al., 2004; Aubert et al., 2005; Westin et al., 2007, Santini, 2009a; Lebel et al., 2010; Rangel-Barajas et al., 2011; Alcacer et al., 2012). Phar- 
macological blockade of D1R, or its genetic ablation, reduces the intensity of LID in animals (Westin et al., 2007; Darmopil et al., 2009). Stimulation of D1R and NMDA glutamate receptors can activate signaling cascades involving CAMP-dependent protein kinase (PKA), dopamine- and cAMP-regulated phosphoprotein of $32 \mathrm{kDa}$ (DARPP-32), and ERK in D1R-expressing MSNs (Valjent et al., 2005). In 6-OHDA-lesioned animals, administration of L-DOPA activates a D1R-dependent Ras-ERK signaling pathway (Gerfen et al., 2002; Westin et al., 2007) that is correlated with the intensity of LID (Schuster et al., 2008; Darmopil et al., 2009; Lindgren et al., 2009; Santini et al., 2009a; Santini et al., 2009b; Lebel et al., 2010; Santini et al., 2010; Francardo et al., 2011). LID is blocked or decreased by pharmacological or genetic inhibition of the ERK pathway (Santini et al., 2007; Fasano et al., 2010). However, the activation of ERK is intense after the first L-DOPA treatment but tends to fade with chronic treatments, even in dyskinetic animals (Santini et al., 2007; Ding et al., 2011). In contrast, the intensity of LID is increased or maintained by repetition of L-DOPA administrations (Lundblad et al., 2005). This suggests that the initial activation of ERK-dependent signaling cascades primes long-lasting changes in the striatal neuronal networks that maintain LID after prolonged treatment (Cenci et al., 2010). These changes could involve gene transcription, a major ERK target, as illustrated by the L-DOPA-induced expression of $\Delta$ FosB that contributes to LID development and maintenance (Andersson et al., 1999; Andersson et al., 2003; Berton et al., 2009; Cao et al., 2010). However, the early patterns of gene expression implicated in LID remain largely unknown. We hypothesized that very early ERK-dependent changes in gene expression play a key role in the later appearance of striatal dysfunction revealed by LID. We therefore investigated ERK-dependent gene expression changes induced by the first administration of L-DOPA and associated with the early development of abnormal involuntary movements in unilaterally 6-OHDA-lesioned mice. Using this strategy, we identified neuronal activity-regulated pentraxin (Narp) as an ERK-dependent gene induced by L-DOPA and showed a decrease of LID in Narp knock-out (KO) mice or after overexpression of the dominant-negative form of Narp in the striatum.

\section{Materials and Methods}

\section{Animals}

Eight-week-old C57BL/6J mice were maintained in a $12 \mathrm{~h}$ light/dark cycle in stable conditions of temperature $\left(22^{\circ} \mathrm{C}\right)$ with access to food and water ad libitum. All experiments were conducted in accordance with the guidelines of the French Agriculture and Forestry Ministry for handling animals (Decree 87-848) and under the approval of the Direction Départementale de la Protection des Populations de Paris (Authorization C-75-828, License B75-05-22). Generation of Narp KO mice has been described previously (Bjartmar et al., 2006). Narp KO and wild-type (WT) control mice were obtained by breeding Narp heterozygotes. Both male and female WT and KO mice were used and their age was 10-11 weeks at the start of lesion.

\section{6-OHDA lesions, AAV injections, and postoperative care}

Mice were anesthetized with a mixture of xylazine $(10 \mathrm{mg} / \mathrm{ml})$ and pentobarbital $(25 \mathrm{mg} / \mathrm{ml}$; Centravet) and mounted in a digitalized stereotaxic frame (Stoelting) equipped with a mouse adaptor. 6-OHDA-HCl $(3.0 \mathrm{mg} / \mathrm{ml}$; Sigma-Aldrich) was dissolved in a solution containing 0.2 $\mathrm{g} / \mathrm{L}$ ascorbic acid and $9 \mathrm{~g} / \mathrm{L} \mathrm{NaCl}$. Mice were lesioned as described previously (Alcacer et al., 2012) by receiving two unilateral injections $(2 \times 2$ $\mu \mathrm{l})$ of 6-OHDA into the right striatum at the following coordinates according to the mouse brain atlas (Paxinos and Franklin, 2001): anteroposterior, $+1.2 \mathrm{~mm}$; lateral, $+2.1 \mathrm{~mm}$; dorsoventral, $-3.2 \mathrm{~mm}$; and anteroposterior, $+0.6 \mathrm{~mm}$; lateral, $+2.4 \mathrm{~mm}$; dorsoventral, $-3.2 \mathrm{~mm}$. A
Narp construct that acts as a dominant negative for WT Narp secretion (Narp-N13; $\Delta 345-416)$, as well as a Narp deletion construct that does not inhibit WT Narp secretion (Narp-N; $\Delta 191-410$; O'Brien et al., 2002) were used to generate adeno-associated virus (AAV) expression constructs as described previously (During et al., 2003). For the AAV experiment, 6-OHDA $(12 \mu \mathrm{g} / \mu \mathrm{l})$ and AAV (AAV-DN13: $3.5 \times 10^{13} \mathrm{vg} / \mathrm{ml}$; AAV-Narp-N: $2.2 \times 10^{13} \mathrm{vg} / \mathrm{ml}$; AAV-eGFP $\left.3.34 \times 10^{13} \mathrm{vg} / \mathrm{ml}\right)$ were injected into the right striatum ( 1 injection, $2 \mu \mathrm{l}$ ) at the following coordinates according to the mouse brain atlas (Paxinos and Franklin, 2001): anteroposterieur, $+0.4 \mathrm{~mm}$; lateral, $+2 \mathrm{~mm}$; dorsoventral, $-3 \mathrm{~mm}$. Each injection was performed with a 36 -gauge, 50 -mm-long stainless steel cannula connected to a syringe pump (MTI Corporation) by a polyethylene catheter, at a slow rate of $0.25 \mu \mathrm{l} / \mathrm{min}$ to minimize tissue damage. After the injection, the cannula was left in place for additional $4 \mathrm{~min}$ before being slowly retracted. Mice were left on a warm plate for $\sim 24 \mathrm{~h}$ after surgery to avoid hypothermia. To reduce suffering, mice received subcutaneous injections of a nonsteroidal anti-inflammatory drug (flunixin meglumine, $4 \mathrm{mg} / \mathrm{kg}$; Sigma-Aldrich) just after the surgery and twice daily for $2 \mathrm{~d}$ after surgery. Mice were allowed to recover for 4 weeks before behavioral evaluation and drug treatment. Dopaminergic depletion in the striatum was assessed by determining the striatal levels of tyrosine hydroxylase (TH) by immunoblotting.

\section{Treatments}

L-DOPA and the peripheral DOPA decarboxylase inhibitor benserazide hydrochloride (Sigma-Aldrich) were dissolved together in physiological saline solution $(9 \mathrm{~g} / \mathrm{L} \mathrm{NaCl})$. In the acute experiments, L-DOPA and benserazide hydrochloride were injected intraperitoneally at a dose of 20 and $12 \mathrm{mg} / \mathrm{kg}$, respectively, in a volume of $10 \mathrm{ml} / \mathrm{kg}$ body weight. $\alpha$-[amino[(4-aminophenyl)thio] methylene]-2-(trifluoromethyl)benzeneacetonitrile (SL327; Sigma-Aldrich) was dissolved in DMSO diluted twice in water (final concentration of DMSO, 50\%) and injected intraperitoneally ( $50 \mathrm{mg} / \mathrm{kg} ; 2 \mathrm{ml} / \mathrm{kg}$ ) $30 \mathrm{~min}$ before injection of L-DOPA. Control mice received the same injection of diluted DMSO without SL327 (vehicle). In the subchronic experiment, mice were treated for $2 \mathrm{~d}$ with L-DOPA $(20 \mathrm{mg} / \mathrm{kg})$ and benserazide hydrochloride $(12 \mathrm{mg} / \mathrm{kg})$ or vehicle separated by a $24 \mathrm{~h}$ interval. Narp KO mice, WT littermates, and AAV-injected mice were treated chronically with L-DOPA and benserazide using an escalating dose protocol $(5,10$, and $20 \mathrm{mg} / \mathrm{kg}$ L-DOPA, i.p., daily for $5 \mathrm{~d}$ for each dose, the benserazide dose remaining fixed at 12 $\mathrm{mg} / \mathrm{kg}$ ). Mice were killed by decapitation.

\section{Behavioral tests}

Cylinder test. The sensorimotor function deficit was evaluated in the cylinder test to estimate Parkinsonism in the various lesioned mice (Lundblad et al., 2002). Mice were placed one by one in glass cylinders and video recorded for $5 \mathrm{~min}$ without previous habituation to the glass cylinder. Once introduced into the cylinder, the mice showed an exploratory behavior reflected by rearing and forepaw contacts on the wall. The number of contacts with the right or left forepaw was counted (only contacts in which the animal supported its body weight on the paw with extended digits). The use of the impaired (left) forepaw was expressed as a percentage of the total number of contacts on the wall.

Abnormal involuntary movement. AIMs were assessed using a previously validated scale for scoring LID in mouse (Lundblad et al., 2004, 2005). Immediately after the L-DOPA administration, mice were placed in separate cages and abnormal movements were assessed for 1 min every $20 \mathrm{~min}$ over a period of $120 \mathrm{~min}$. Abnormal movements, clearly distinct from natural stereotyped behaviors, were classified into four different subtypes: locomotive (tight contralateral turns), axial (contralateral dystonic posture of the neck and upper body), limb (jerky and fluttering movements of the limb contralateral to the side of the lesion), and orofacial (vacuous jaw movements and tongue protrusions) AIMs. Each subtype was scored on a severity scale from 0 to 4 where $0=$ absent, $1=$ occasional, 2 frequent, $3=$ continuous, and $4=$ continuous and not interruptible by external stimuli. A composite axial, limb, and orofacial (ALO) dyskinesia score was obtained by the addition of scores for axial, limb, and orofacial AIMs. To identify the extreme behaviors in the subchronic experiment, highly and weakly dyskinetic mice were separated by 
A

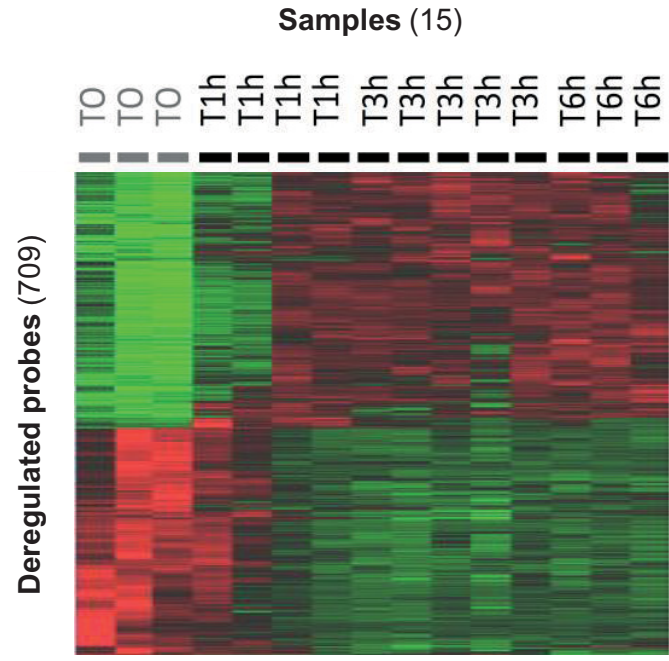

Probe intensity:

Low High

C

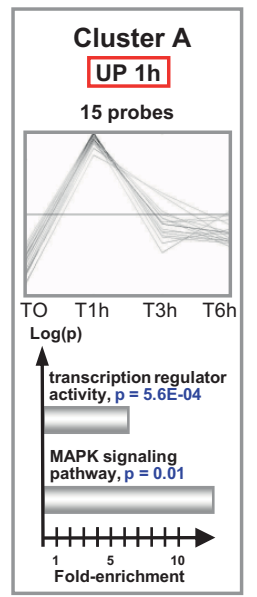

B

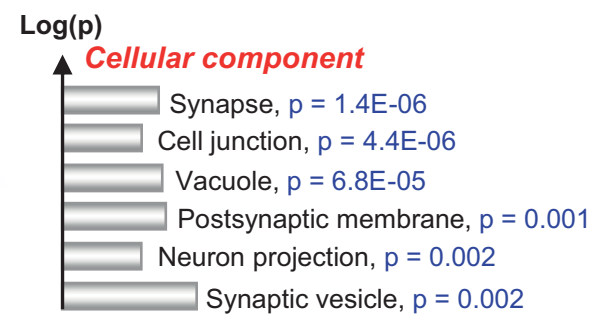

Molecular function

Actin binding, $p=2.6 \mathrm{E}-04$

Substrate specific channel activity, $p=9.8 E-04$

Calmodulin binding, $p=0.005$

Protein phosphatase regulator activity, $p=0.005$

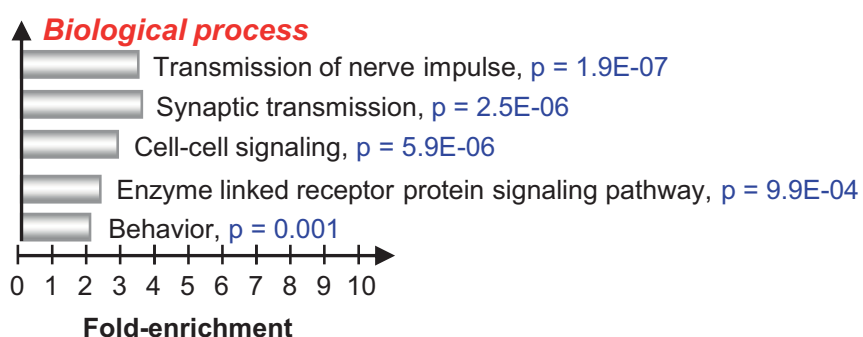

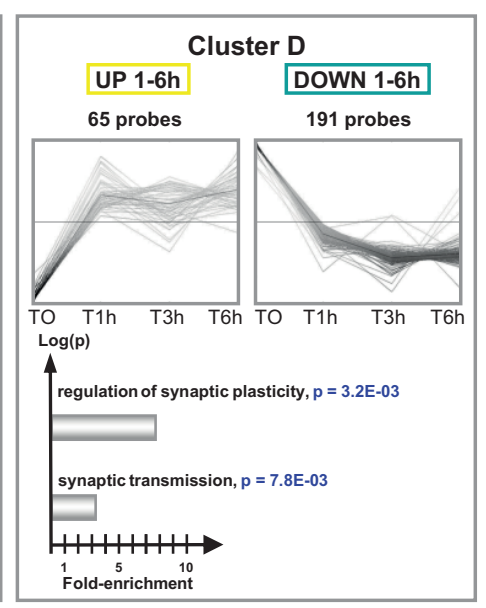

Figure 1. Gene expression signature in the 6-OHDA-denervated striatum after an acute L-DOPA administration. $A$, Hierarchical clustering (individual data) performed on the 709 probes significantly deregulated after an acute L-DOPA administration (fold change $>1.2, p<0.01, \mathrm{FDR}<0.1$ ). Fifteen samples were analyzed in this experiment (T0, $n=3 ; \mathrm{T} 1 \mathrm{~h}, n=4 ; \mathrm{T} 3 \mathrm{~h}, n=5 ; \mathrm{T} 6 \mathrm{~h}$, $n=3$ ). The clustering image was obtained using average dot product distance metric selection and average linkage clustering methods with Multi Experiment Viewer software. The green probes correspond to downregulated genes and red ones correspond to upregulated genes. $\boldsymbol{B}$, Nonredundant gene ontology analysis (molecular functions, biological process, and cellular components) of the 709 probes list. The analysis was conducted using the functional annotation tool of the David Bioinformation database. Gene ontology pathways with $>3$ genes were considered significant if fold enrichment was $>2$-fold and the modified Fisher exact $p$-value was $<0.01$. C, Identification of four gene clusters corresponding to the different temporal expression profiles of the 709 probes. The name of genes in each cluster is specified in the Table 1. The data were obtained using an unbiased self-organizing tree algorithm (Pearson correlation in SOTA, Multi Experiment Viewer software). For each cluster, the top shows the time course during the L-DOPA challenge and the bottom shows the results of gene ontology analysis (performed as for $\boldsymbol{B}$ ).

a quartile analysis based on ALO score. For the Narp KO mice experiment, assessments were performed in blind conditions by a rater ignoring the mouse genotype.

\section{$R N A$ processing}

At the corresponding time points, mice were killed and the striata were dissected with a standardized frozen-based procedure to avoid RNA degradation. After decapitation and dissection, the brain of mice were rapidly frozen by immersion for $1 \mathrm{~min}$ in isopentane maintained at $-30^{\circ} \mathrm{C}$ in dry ice. Coronal sections $(210 \mu \mathrm{m}$ thick) were cut with a cryostat and microdisks of striatum were dissected. The samples were stored at $-80^{\circ} \mathrm{C}$ until RNA extraction processing. Total mRNA was extracted using the RNeasyMiniKit (Qiagen) according to the manufacturer's procedure and further controlled for RNA quality (Bioanalyser 2100; Agilent). Next, total mRNA was amplified, labeled (Illumina TotalPrep RNA Amplification Kit; Ambion), and hybridized on Illumina Mouse WG-6v3.0 bead chips ( $>43000$ probes) at the P3S facility using Illumina's protocol. The Beadchips were scanned on an Illumina IScan with Illumina IScan image data acquisition software (www.illumina.com). To avoid batch effects, sample order processing was randomized. Biological replicate samples of $250 \mathrm{ng}$ of total RNA were reverse transcribed at $25^{\circ} \mathrm{C}$ for 10 $\min , 37^{\circ} \mathrm{C}$ for $2 \mathrm{~h}$, and $85^{\circ} \mathrm{C}$ for $5 \mathrm{~min}$ in a $20 \mu \mathrm{l}$ reaction buffer according to manufacturer's instructions. Quantification of mRNAs was performed by real-time RT-PCR using a Roche LightCycler LC480 sequence detection system. Oligonucleotide primer pairs were obtained from 
Table 1. List of genes significantly deregulated after an acute challenge of L-DOPA

\begin{tabular}{|c|c|c|c|c|c|c|c|}
\hline \multirow{2}{*}{$\begin{array}{l}\text { Cluster A } \\
\text { Peaked } 1 \mathrm{~h} \text { (UP) } \\
\end{array}$} & \multicolumn{7}{|l|}{ Cluster B } \\
\hline & \multicolumn{5}{|l|}{ Peaked 3 h (UP) } & \multicolumn{2}{|l|}{ Peaked $3 \mathrm{~h}$ (DOWN) } \\
\hline Egr4 & Per2 & Nedd4l & Ppp2r2d & Caskin2 & Erlin1 & Tax1bp3 & Vstm2a \\
\hline Egr2 & SIc32a1 & Fkbp5 & Pkp2 & Atp2a2 & D430042009Rik & $\mathrm{C} 2 \mathrm{~cd} 4 \mathrm{c}$ & Fam113a \\
\hline Per1 & Vgf & Prosapip1 & Ddit4l & Vti1b & Cdc42ep3 & BC046404 & Insc \\
\hline Per1 & Gas7 & Cacna1 h & Abi2 & A930005I04Rik & Ndufa8 & Tmem141 & Epha5 \\
\hline Npas4 & Al464131 & Ece1 & Zfp280d & Ppapdc2 & Eif4ebp2 & Pgpep1 & Fcgrt \\
\hline Mfap3 & Arpp21 & Csmd3 & Smug1 & 2700062C07Rik & Rit2 & Chrm2 & Sypl \\
\hline Dusp1 & Crym & Ntrk3 & $\mathrm{C} 8 \mathrm{~b}$ & Ubxn6 & Cacna2d3 & Tax1bp3 & Mela \\
\hline Junb & Spry3 & 1110018G07Rik & Cinp & Wrb & Cenyl1 & Araf & Nfatc3 \\
\hline Arc & Syt4 & Sbk1 & Rerg & Sez6 & Zcchc12 & Hexb & Abca7 \\
\hline Fos & Vdac1 & Car12 & $2 \mathrm{fp} 385 \mathrm{~b}$ & Spag6 & Foxp1 & Ctsb & Pgpep1 \\
\hline FosB & Nrarp & Kcnd2 & Itgb1bp1 & Rab15 & Nptx2 & Rab8a & F11r \\
\hline Dusp6 & Doc $2 b$ & Gabarapl1 & $\mathrm{Kdm} 4 \mathrm{~b}$ & Kcnab1 & Gng7 & Trappc1 & Wwtr1 \\
\hline Frat2 & Camk1g & Zeb1 & Homer1 & Ippk & Nit1 & Vangl2 & Eif6 \\
\hline Dusp6 & Fam184b & SIc25a44 & Vdac1 & Mbp & Lmtk2 & $V \operatorname{tn}$ & Gns \\
\hline \multirow[t]{16}{*}{ Nab2 } & Gdnf & Dmkn & Fdps & Chat & Foxo1 & Lpar4 & Syt12 \\
\hline & Ppp3r1 & Нрса & Ndufa5 & $\mathrm{Sc} 4 \mathrm{~mol}$ & Astn1 & Tusc1 & Fam125a \\
\hline & Pard6a & Nsg2 & Capn10 & 1810046J19Rik & Mpp6 & Tpm2 & Sp7 \\
\hline & Gnb5 & $\mathrm{Abi} 2$ & Gne & Tmem41b & Psmc3ip & Lpar4 & Trib3 \\
\hline & Taf9b & Ido1 & Zmynd8 & Unc119b & Prpf18 & Cmtm8 & Fam3a \\
\hline & Dgkb & Gabrb3 & Ncor1 & 1110017D15Rik & Tiam2 & 41161 & Tex261 \\
\hline & Gria2 & Ajap1 & Csrnp3 & Sf3a1 & Dmkn & 9130019022Rik & Naprt1 \\
\hline & Kcnab1 & Clic6 & Zfhx3 & Dcaf4 & Nphp4 & 3632451006Rik & SIc2a6 \\
\hline & Shank3 & SIc2a1 & Pfkp & 2610034M16Rik & Grid2 & Apba2 & 2810474019Rik \\
\hline & $\mathrm{N}+5 \mathrm{e}$ & Datn3 & Reln & Kcnk1 & & Ifnar2 & Tmc6 \\
\hline & Per2 & Agfg2 & Dnajc2 & Banf1 & & Egfl7 & 2210016L21Rik \\
\hline & Fam132a & Atg1611 & Pde4dip & Tdrkh & & Fam114a1 & Add3 \\
\hline & Tiam1 & Mat2a & Pitpnm3 & SIc22a17 & & cdc42ep2 & Pdgfa \\
\hline & $\mathrm{N}+5 \mathrm{e}$ & Ubfd1 & 4833424015Rik & Prkg2 & & Plekho2 & Lor \\
\hline & Gucy1a3 & Tmem70 & Rem2 & $\mathrm{Kdm} 5 \mathrm{~b}$ & & Gkap1 & Rnf135 \\
\hline & Kcna5 & Pptc7 & Corn4l & Fem $1 b$ & & Lgals8 & \\
\hline \multicolumn{8}{|l|}{ Cluster C } \\
\hline \multicolumn{5}{|l|}{ Peaked $6 \mathrm{~h}$ (UP) } & \multicolumn{3}{|l|}{ Peaked $6 \mathrm{~h}$ (DOWN) } \\
\hline Lrrc1 & Znrf1 & Ppp1cc & Rgs14 & Sfxn3 & Sncb & Nav1 & $\operatorname{Cln} 6$ \\
\hline Unc13c & Zfp930 & Casz1 & Rundc3b & Cyld & Aspscr1 & Plekha2 & Acta2 \\
\hline Ino80e & Nsg2 & Sh3bgrl3 & Ylpm1 & Rhobtb2 & Tpd52 & Psap & Serac1 \\
\hline $\mathrm{Mfs} 2 \mathrm{~d} \mathrm{a}$ & SImap & Hs6st2 & SIc2a13 & Chst11 & $\mathrm{Hdac7}$ & Vamp1 & $\mathrm{Rfc} 2$ \\
\hline Pdzd2 & H2afx & C1galt1c1 & $\mathrm{Tac1}$ & 1110057K04Rik & Triobp & Metap1d & Adck4 \\
\hline Syne1 & Ecel1 & Vldlr & SIc10a4 & Tmem199 & Tmem141 & Skap1 & BC017647 \\
\hline Rap1gap & Ppp2r2a & Ppp2r2c & Penk & Grb10 & Aifm2 & $\mathrm{Nol3}$ & Pld4 \\
\hline Th & Dazl & Krt10 & Srm & Tle1 & Ptprd & Nos1ap & Tmed10 \\
\hline Clip4 & VIdlr & Sorcs2 & Eps15l1 & Rhobtb2 & $\mathrm{Ldb2}$ & Ptbp1 & Ccs \\
\hline Pcsk2 & Musk & Arg2 & Ptk2b & Crtc1 & Reep3 & Tcf4 & Ednrb \\
\hline Gpr158 & Lypd1 & Gpd1 & Ubl3 & Dab1 & Rab3d & Wipf1 & 2310003H01Rik \\
\hline Lingo3 & Adra2c & Epb4.9 & Mterfd3 & Ets2 & Tmem $106 c$ & Npm3 & Sepn1 \\
\hline Spock3 & Myo5b & Amigo2 & Rhbdl3 & Bahd1 & Tmc6 & Klf6 & Psap \\
\hline Trnp1 & Mbnl2 & 4933424B01Rik & Slc25a14 & Wdr37 & Ptprd & $\mathrm{Nol} 3$ & Kcna6 \\
\hline Smpd3 & 1110003E01Rik & Abi1 & Sdr39u1 & Cacnb2 & Cmtm4 & Vat1 & Hcls1 \\
\hline Onecut2 & $C x \times 1 c$ & Rasgrp1 & VIdlr & Mbnl2 & Alpl & Abhd14b & Kcne1l \\
\hline Сур2с44 & Gpr158 & Ddost & Strn & Mdga2 & Golim4 & Fam189a1 & Fam126a \\
\hline Rarb & C030019105Rik & Lrrtm3 & SIC2a13 & Pcdhgb4 & Fah & Tnfaip1 & Fam105b \\
\hline Dlg2 & Jph3 & Sub1 & Fnip1 & $\mathrm{Kdm} 3 \mathrm{a}$ & Glb1 & Ptbp1 & Btbd3 \\
\hline Arpp19 & Rilp & Cong2 & Ncbp1 & Spink8 & Pinx1 & Gpd2 & Dcakd \\
\hline Ppp1r2 & Dgki & Trpc3 & Ndufs4 & Fbll1 & 1700084C01Rik & Fchsd1 & Gm4671 \\
\hline Gdf10 & Tmcc2 & Pkia & Dixdc1 & Rilpl1 & Slc6a7 & Padi2 & \\
\hline Trerf1 & Mxd1 & Vat1l & Zfp758 & Ube3c & Sox9 & Skp2 & \\
\hline Ppp4r4 & Dlk1 & Coch & Zfp39 & Tmem49 & Slc38a2 & $\mathrm{Nol} 3$ & \\
\hline Ramp1 & Gps1 & Wdr17 & $\mathrm{Mtf2}$ & Сур2а5 & Prkd3 & Nasp & \\
\hline Mapkap1 & Pcsk2 & Scrn1 & B3galt5 & Pfn2 & Npm3-ps1 & Opalin & \\
\hline E130309F12Rik & $\operatorname{Scg} 5$ & Zfp523 & Aplp1 & Myo1b & Gna13 & Nav1 & \\
\hline Dbp & Gm5868 & Car12 & Lyar & Tbp & Ctnnbip1 & Pcyt2 & \\
\hline Itpka & Ctxn1 & Ufsp1 & Ttyh1 & Ppp2r5e & Wnt7b & Parm1 & \\
\hline Pcsk2 & Epor & Kars & Sipa1l3 & & Ptgis & Mical1 & \\
\hline \multirow[t]{2}{*}{ Cbr3 } & Upb1 & Socs 5 & Kdm3a & & Srprb & Mobkl2a & \\
\hline & & & & & & & (Tabel Continues) \\
\hline
\end{tabular}


Table 1. Continued

\begin{tabular}{|c|c|c|c|c|c|c|c|}
\hline \multicolumn{8}{|l|}{ Cluster D } \\
\hline \multicolumn{3}{|l|}{ UP 1-6h } & \multicolumn{5}{|l|}{ DOWN 1-6h } \\
\hline Nomo1 & Ppp1r1b & Klf16 & Gm10762 & Cldn5 & Ctsz & Igfbp2 & Lix1 \\
\hline Dgat2 & Tsen2 & Mrps21 & Dennd1c & Ctsc & Dlgap1 & Gnas & Cotl1 \\
\hline Ttc17 & Hnrnpl & Zfp281 & Fam38b & Map3k1 & Zeb2 & SIC29a3 & Fam81a \\
\hline Ppp1r13b & Rundc3a & Ccbl1 & Satb1 & Stxbp1 & Syn1 & Vamp1 & Myo9b \\
\hline 0azz-ps & $\operatorname{lnpp5f}$ & Plk2 & Triobp & Cib2 & $\| 18 \mathrm{bp}$ & $\| 4 i_{1}$ & Fadd \\
\hline Fstl4 & 2010011|20Rik & Atxn1 & SIc22a18 & Fcgrt & Tcirg1 & Chrna4 & Tmem63b \\
\hline KIf9 & Rpap2 & Ngef & Laptm5 & Klhl6 & Fes & Eif4g2 & $\operatorname{Tnr}$ \\
\hline Arl3 & $S c n 4 b$ & Tspan3 & Mmp14 & Cnih3 & 1700019N12Rik & Chchd8 & Naglu \\
\hline Bai2 & Hras1 & Agpat1 & Cdkn1c & Pvalb & Gstm2 & Chac1 & 2210012G02Rik \\
\hline Sec14l1 & Rpusd1 & Sap130 & Rab13 & Tnfrsf19 & Mitf & Axl & Cebpg \\
\hline Gapdh & $\mathrm{C} 2 \mathrm{~cd} 2 \mathrm{I}$ & Romo1 & Rell1 & Rassf5 & Rapgefl1 & Sh3pxd2b & Ncf4 \\
\hline Hbegf & Ppp1r1b & Amz2 & Kenc4 & Bicc1 & Ptprz1 & Lasp1 & Lamp2 \\
\hline Scube3 & D2Wsu81e & Abcb8 & 2210411K11Rik & Sobp & Gabra3 & Pqlc2 & Vps13a \\
\hline Cap1 & Fam196b & Rbak & Ptplad2 & Prickle1 & Plek & Iqgap1 & Robo2 \\
\hline Gpc3 & Coro2b & Palm & Klhl6 & Iqgap1 & Lag3 & Slamf9 & 9030612E09Rik \\
\hline Ubqln4 & Cox5b & Zfp704 & SIc24a6 & Hexa & $\mathrm{Bbc3}$ & Tirap & Aggf1 \\
\hline Sec14l1 & Meis2 & Siah2 & Fxyd5 & Mrpl48 & Arhgap4 & Palm2 & Mak16 \\
\hline Taok1 & Gm129 & Darc & Col4a1 & Arhgef19 & P2ry6 & Paox & Hcst \\
\hline Mrpl33 & Cry2 & Gdf1 & $\mathrm{Cd} 200$ & Lat2 & Pik3r1 & Htatip2 & Bach1 \\
\hline Trnp1 & Cited4 & Rc3h2 & Slc44a2 & Plcg2 & Pik3cg & Myo9b & Pgm2l1 \\
\hline Thoc4 & Sec14l1 & St8sia3 & Mef2c & Hecw1 & Ftl1 & Tab2 & $\mathrm{H} 2-\mathrm{K} 1$ \\
\hline Tmem90a & Acy1 & & Clec2d & S1pr2 & Stab1 & Tgoln1 & Grin1 \\
\hline & & & Arap1 & Fbln1 & Pik3r1 & Pa2g4 & Ppm11 \\
\hline & & & Aif1 & Trim25 & Dpp7 & Hvcn1 & Crtac1 \\
\hline & & & Mef2c & Cyth4 & Hspb6 & Cask & $\mathrm{Cd} 63$ \\
\hline & & & Faah & Ctsz & Atp2a3 & 2410066E13Rik & 2700060E02Rik \\
\hline & & & Fadd & Mocs1 & Sobp & Shc1 & $\mathrm{Rbl} 2$ \\
\hline & & & Renbp & Gfap & 2810416G20Rik & Serpinb6a & Daam1 \\
\hline & & & Chst8 & 0asl2 & Hapln4 & Il11ra1 & Gabrg2 \\
\hline & & & Ranbp3| & $\mathrm{Npc2}$ & SIC24a2 & Cond1 & Sepx1 \\
\hline & & & Igfbp5 & Arrb2 & Myl4 & Efna5 & Srpk3 \\
\hline & & & Lpp & Sox5 & Syn2 & Rsrc2 & Fxyd5 \\
\hline & & & Sh3gl2 & Fadd & Fcrls & St3gal5 & Fbln2 \\
\hline & & & Rims1 & Abi3 & Snx9 & Htatip2 & $c 4 b$ \\
\hline & & & $\mathrm{CxCl} 12$ & $\mathrm{Rbm} 6$ & Wdr1 & $\operatorname{Pdcd} 4$ & 0ma1 \\
\hline & & & Ptprt & Nuak1 & Lmna & Adar & \\
\hline & & & Mapk11 & Ganc & C4a & Capg & \\
\hline & & & Tcirg1 & Gstm2 & Gatad2b & Il11ra1 & \\
\hline & & & Ltbp1 & Uap1l1 & Fgfr1op & C1qa & \\
\hline
\end{tabular}

The regulated mRNAs are identified by their official gene symbol. Each cluster is identified by the direction (UP: up-regulated, DOWN: down-regulated) and the peak of deregulation (1,3, or $6 \mathrm{~h}$ after injection of L-DOPA). Genes are then sorted among the cluster by $p$-values. Genes in bold are those used for Figure 2 .

MWG Operon, designed with Oligo Explorer 1.0, and verified for specificity with the NCBI Blast engine (www.ncbi.nlm.nih.gov/BLAST) using the "nearly exact short match" program. The forward and reverse oligonucleotides used for Nptx2, FosB, and Th were 5'-TTTGATGCCAC GCAGGCCTTTGT-3' and 5' -TGGATCGTGGCCTCTGGGACG-3' ${ }^{\prime}$ 5' $^{\prime}$ CCGTGAAACCGACAGAG-3' and $5^{\prime}$-GAGTGGAATGAGATGCGAG$3^{\prime}, 5^{\prime}$-AGGTCCGGGCCTTTGACCCA- $3^{\prime}$ and 5' $^{\prime}$-AGCGCCGGATGGT GTGAGGA-3' respectively. The end point PCR (35 cycles) was performed with LightCycler 480 SYBER Green I master (Roche) on $20 \mathrm{ng}$ of RT product. After amplification, PCR products were analyzed by the melting curve to confirm the amplification specificity. The relative levels of mRNA were standardized using 36b4 ribosomal RNA as the nonvariant RNA. The quantitative RT-PCR on each sample was performed in triplicate. Expression values were determined using the $\Delta \Delta$ CT method.

\section{Immunoblotting}

Samples were homogenized in 1\% SDS, equalized for their content in protein, and analyzed by Western blot. Homogenates were subject to SDS-PAGE on Bis-Tris gradient gels (4-12\%; Invitrogen) with standard transfer and preblocking procedures. Membranes were incubated in a primary antibody overnight at $4^{\circ} \mathrm{C}$. The antibody dilutions were 1:1000, $1: 10000,1: 4000,1: 2000,1: 1000$, and 1:1000 for primary antibodies corresponding to phospho-Thr202/Tyr204-ERK1/2 (Millipore), ERK1/2
(Sigma-Aldrich), TH (Sigma-Aldrich), Golf (Hervé et al., 1993), DARPP-32 (Gift from P.Greengard, Rockefeller University, New York, NY), and Narp (Tsui et al., 1996), respectively. Membranes were washed and incubated in a secondary antibody for $60 \mathrm{~min}$ at room temperature and then washed again. Secondary antibodies (1:4000) were IRDye 700DX-conjugated anti-rabbit IgG and IRDye 800CW-conjugated antimouse IgG (Rockland Immunochemical). Their binding was quantified using an Odyssey (LI-COR) infrared fluorescent detection system. Quantification was performed using Odyssey software (Odyssey infrared imaging system application, software version 1.2.15). The levels of phosphoproteins were normalized for the amount of the corresponding total protein detected in the sample.

\section{Data analysis and statistics}

Quality control of microarray was performed using Bead Studio (Illumina Genome Studio Software) and LumiR (www.bioconductor.org). Microarray data normalization on median and background was conducted using Bead Studio software (Illumina). Quality control before any array analysis included visualization of array scan images and observation of different quality markers of hybridization and homogeneity of expression, including, notably, the determination of signal/noise ratio, the average of detected genes, or the density of expression intensity. Microarrays for which $>4$ of the 16 observed indicators differed by $>2$ $\mathrm{SDs}$ from the mean were considered as bad quality control and were not 
A

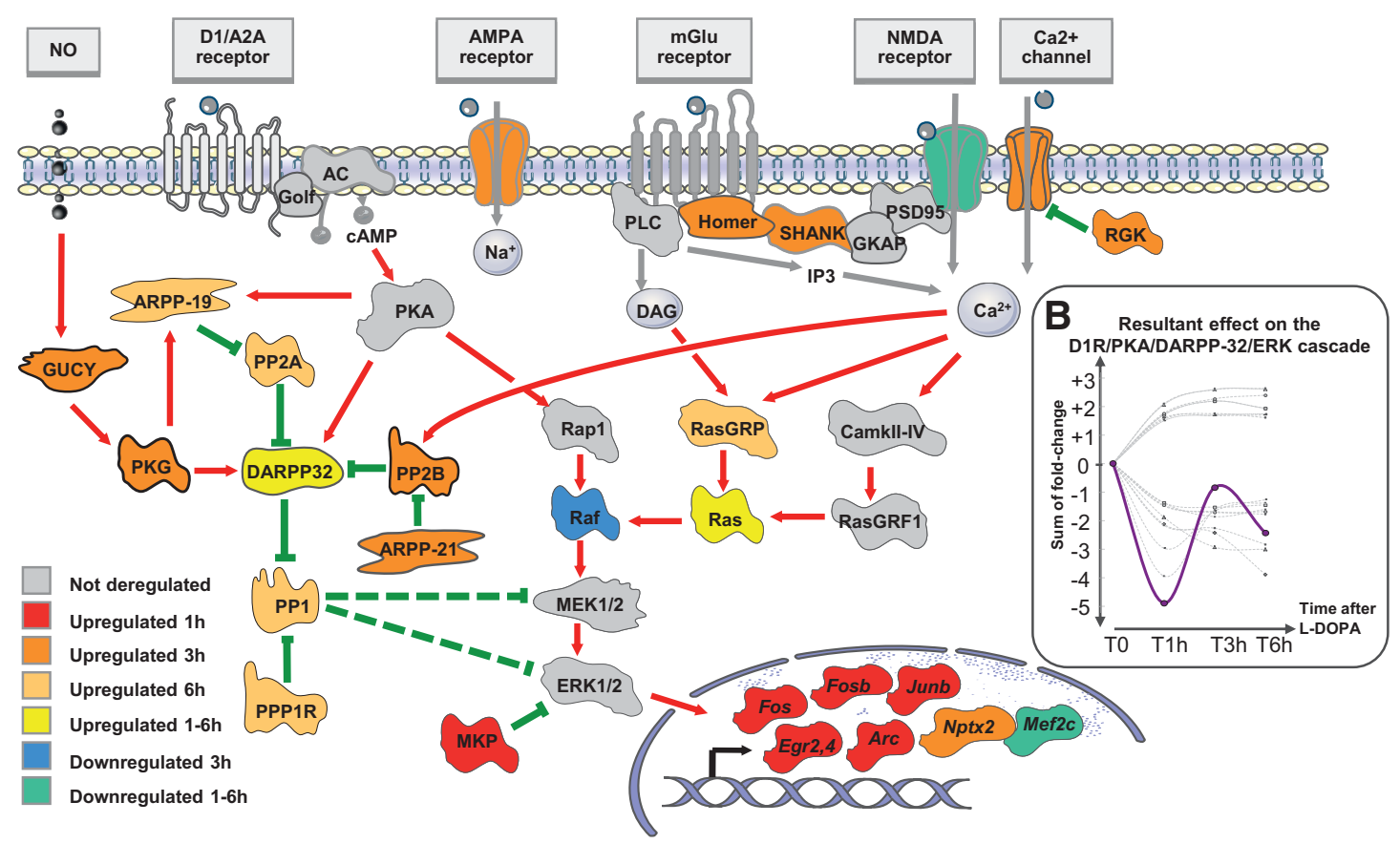

Figure 2. Model of the regulation of the D1R/PKA/DARPP-32/ERK cascade after an acute L-DOPA administration. $\boldsymbol{A}$, The proteins - or multiprotein complexes—of the D1R/PKA/DARPP-32/ERK are presented using different colors according to the time and the direction (up or down) of regulation of the corresponding gene(s) after the acute challenge of $\mathrm{L}-\mathrm{DOPA}$. Deregulated genes used for the figure are indicated in brackets: AMPA receptor: glutamate receptor ionotropic AMPA 2 (Gria2); NMDA receptor: glutamate receptor ionotropic NMDA 1 (Grin1) and Glutamate receptor ionotropic delta-2 (Grid2); Ca ${ }^{2+}$ channel: voltage-dependent calcium channel (Cacna1h, Cacna2d3, and Cacnb2); Homer (Homer1); SHANK (Shank3); RGK (Rem2); ARPP-19; CAMP-regulated protein kinase of 19 kDa (Arpp-19); GUCY: guanylate cyclase (Gucy1a3); PKG: GGMP-dependent protein kinase (Prkg2); PP2A: protein phosphatase 2A (Ppp2r2a, Ppp2r2c, Ppp2r2d, Ppp2r5e); PP2B: protein phosphatase 2B (Ppp3r1); PP1: protein phosphatase 1 (Ppp1cc); PPP1R2: inhibitor-2 (Ppp1r2); MKP: MAP-kinase phosphatase (Dusp1, Dusp6); Raf (Araf); Ras (Hras1); RasGRP: RAS guanyl-releasing protein 1 (Rasgrp1). IEGs are also displayed (Fos, FosB, Junb, Egr2, Egr4,Arc,Nptx2, Mef2c). B, Putative resultant effect on the D1R/PKA/DARPP-32/ERK cascade deregulation. A value corresponding to the fold change expression at each time point was attributed to each actor of the cascade with a positive $(+1)$ or negative $(-1)$ valence according to the expected effect on ERK activation. The purple curve corresponds to the overall resulting effect on ERK activation calculated as the arithmetic sum of each individual effect (gray curves). A negative value represents a putative downregulation of ERK activation; a positive value represents a putative upregulation of ERK activation.

included for further analyses. Over all of the experiments, $91 \%$ of microarrays passed the quality control. Microarray statistical analyses were performed using the Biometric Research Branch array tolls (http://linus. nci.nih.gov/BRB-ArrayTools.html) and the Multi Experiment Viewer software (MeV4.0; Saeed et al., 2003). General filters were applied before analysis and consisted of thresholding the minimal expression intensity at a value of 10 and in excluding probes if percentage missing exceeded $50 \%$. Genes were identified as differentially expressed if they had a fold difference $>1.2$, if the univariate $p$-value was $<0.01$, and if the false discovery rate $(\mathrm{FDR})$ was $<0.1$. For tests on a small number of genes, the FDR has not been applied but is shown in the tables anyway. Ontology analysis was assessed by using the functional annotation tool of the David Bioinformation database (http://david.abcc.ncifcrf.gov/; Huang da et al., 2009a, 2009b). A clustering image was obtained using average linkage clustering method with Multi Experiment Viewer software.

For blot quantifications, quantitative RT-PCR, and behavioral assessments, data are expressed as mean \pm SEM. Comparisons between groups were performed using Mann-Whitney (for two groups) or Kruskal-Wallis ANOVA (for more than two groups). When two independent factors were analyzed (e.g., lesion and treatment or genotype and treatment), a 2-way ANOVA was used, followed by a Newman-Keuls post hoc test. An ANOVA for repeated measures was performed to analyze behavioral experiments. All analyses were performed using Statistica version 9.1 software (StatSoft).

\section{Results}

\section{Acute L-DOPA signature}

To identify the gene expression signature induced by an acute treatment with L-DOPA in the dopamine-denervated striatum, mice were treated with L-DOPA $20 \mathrm{mg} / \mathrm{kg}+$ benserazide 12 $\mathrm{mg} / \mathrm{kg}$ intraperitoneally 4 weeks after unilateral injection of 6-OHDA into the striatum. The mice were killed $0,1,3$, or $6 \mathrm{~h}$ after treatment to explore the time course of effects. Total mRNA was extracted from the dorsal striatum using a rapid freezing procedure to preserve RNA integrity (see Materials and Methods). Fifteen samples passed our quality control criteria and were retained for further analyses. After filtering, 11029 probes were analyzed. We found 709 probes significantly deregulated at different time points, 376 were upregulated and 333 were downregulated ( $F$ test, univariate $p<0.01$, FDR $<0.1$; Fig. $1 A$, Table $1)$. The gene ontology analysis of this acute L-DOPA-induced gene expression signature showed significant enrichment in synapse-associated genes, synaptic transmission, and protein phosphatase activity (Fig. 1B). We identified four temporal profiles of gene expression by applying an unbiased self-organizing tree algorithm [self-organizing tree algorithm (SOTA), Multi Experiment Viewer software] on the 709 probes induced by L-DOPA (Fig. 1C, Table 1). Genes with a peak of expression $1 \mathrm{~h}$ after L-DOPA treatment belonged to "transcription regulator activity" and "MAPK signaling" pathways (Fig. 1C, cluster A). Not surprisingly, this cluster was composed of several immediate early genes (IEGs) known to be quickly induced by L-DOPA (Fos, FosB, Junb, Egr2, Egr4, Nab2, and Arc) in 6-OHDA-lesioned animals (Berke et al., 1998). The second cluster (cluster B) corresponded to genes with a maximal change of expression at $3 \mathrm{~h}$ either upregulated or downregulated. Genes in this cluster be- 
longed to "long-term depression" and "gated channel activity" Gene Ontology pathways. The genes with a maximal deregulation at $6 \mathrm{~h}$ (cluster $\mathrm{C}$ ) corresponded to genes with significant enrichment in the "protein phosphatase regulator activity." Finally, we found a cluster of longlasting deregulated genes (1-6 h, cluster D), which was enriched in genes belonging to the "synaptic plasticity" and "synaptic transmission" pathways. Several genes deregulated by L-DOPA encoded proteins potentially involved in D1R/ PKA/DARPP-32/ERK signaling pathways (Table 1). After a dramatic but transient increase of dual-phosphatases mRNA (Dusp1 and Dusp6, peak of expression at $1 \mathrm{~h}$ ), we observed a complex, long-lasting regulation of genes encoding protein phosphatase subunits. Ppplcc (protein phosphatase 1 , catalytic subunit, gamma isoform) and Ppp1r2 (protein phosphatase 1 inhibitor 2) were upregulated with a maximal effect $6 \mathrm{~h}$ after L-DOPA. Ppp3r1 (PP2B calcineurin B, type I) was upregulated with a more rapid peak of deregulation $3 \mathrm{~h}$ after L-DOPA. Finally, several subunits of PP2A were upregulated: Ppp2r2a (regulatory subunit B, PR 52, $\alpha$ isoform of PP2A), $P p p 2 r 2 c$ (regulatory subunit $\mathrm{B}, \mathrm{PR} 52$, gamma isoform of $\mathrm{PP} 2 \mathrm{~A}$ ), and $P p p 2 r 5 e$ (regulatory subunit B, B56, $\varepsilon$ isoform of PP2A) with a maximal upregulation $6 \mathrm{~h}$ after L-DOPA and Ppp2r2d (regulatory subunit B (PR55), delta isoform of PP2A) with a maximal upregulation $3 \mathrm{~h}$ after L-DOPA. Because these phosphatases may regulate the DIR/PKA/DARPP-32/ERK pathway in different ways, we wondered whether the molecular signature in response to L-DOPA would ultimately result in a positive or negative feedback upon the cascade. We represented deregulated genes in a model of the D1R/PKA/DARPP-32/ERK signaling pathways (Fig. 2A). To approximately model the overall effect of L-DOPA, we attributed to each molecular actor of the cascade a positive $(+1)$ or negative $(-1)$ valence according to its expected effect on ERK activation and a value corresponding to its fold-change expression after L-DOPA. The sum of the effects calculated at different time points suggested a rapid negative feedback on the D1R/PKA/DARPP-32/ERK cascade followed by an incomplete return to the basal state (Fig. $2 B$ ). This global negative feedback of the cascade would be an attractive explanation for the progressive decrease in ERK activation that has been observed after repeated administration of L-DOPA in nonhuman primates (Santini et al., 2010).

\section{ERK-dependent genes}

Because the inhibition of ERK activation was previously demonstrated to decrease L-DOPA-induced AIMs in lesioned mice (Santini et al., 2007; Fasano et al., 2010), we decided to identify genes regulated by ERK activity among those in the above L-DOPA-induced signature. To block ERK activation, the MEK inhibitor SL327 $(50 \mathrm{mg} / \mathrm{kg})$ or vehicle was administered intraperitoneally $30 \mathrm{~min}$ before L-DOPA in a new experiment. Some mice were killed $3 \mathrm{~h}$ after L-DOPA, the time for which we found the highest number of deregulated genes, and another group of mice were killed 30 min after L-DOPA to study the effect of SL327
B

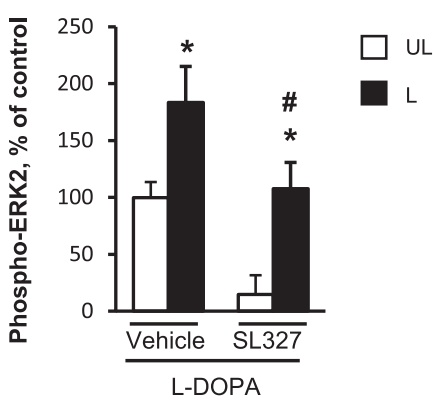

L-DOPA
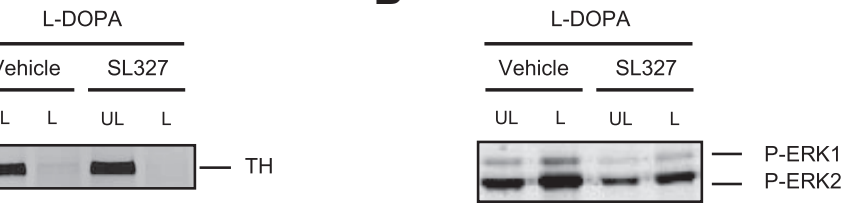

Figure 3. Striatal dopamine depletion induced by 6-OHDA and ERK inhibition by SL327 in L-DOPA treated mice. A, Comparison of dopamine depletion in vehicle/L-DOPA-treated and SL327/L-DOPA-treated mice. Dopamine depletion in the striatum was assessed by determining the striatal levels of TH by immunoblotting in the 6-OHDA-lesioned ( $\mathrm{L}$ ) and unlesioned striata (UL) in mice Comparison of ERK phosphorylation in vehicle/L-DOPA-treated $(n=4)$ and SL327/L-DOPA-treated $(n=4)$ mice. Phospho-ERK1,2 correspond to percentage of the mean in the unlesioned-vehicle samples and are expressed as means + SEM. ${ }^{*} p<0.05$, L versus $\mathrm{UL}, \# p<0.05$, SL327 versus vehicle, post hoc test.

on ERK phosphorylation. By immunoblot, we confirmed that the level of dopamine depletion as evaluated by tyrosine hydroxylase levels was similar between the groups (vehicle or SL327-treated mice: 2-way ANOVA, lesion effect: $F_{(1,46)}=59.3, p<0.001$; SL327 effect: $F_{(1,46)}=0.14$, not significant (ns); lesion and SL327 interaction: $F_{(1,46)}=0.002$, ns; Figure $3 A$ ) and that ERK phosphorylation was increased in the 6-OHDA-lesioned side compared with the unlesioned side and decreased in the striatum of SL327-treated animals (2-way ANOVA, lesion effect: $F_{(1,12)}=$ $15.4, p<0.01$; SL327 effect: $F_{(1,12)}=12.8, p<0.01$, SL327 effect; interaction: $F_{(1,12)}=0.8$, ns; Figure $\left.3 B\right)$. To selectively identify the genes for which deregulation by L-DOPA was blocked by the SL327, we restricted the analysis to the 709 probes deregulated by L-DOPA and identified those with expression that varied in the opposite direction (e.g., upregulated with L-DOPA compared with vehicle, and downregulated when mice were treated with L-DOPA + SL327 compared with L-DOPA + vehicle). We found 28 genes significantly blocked by SL327 by using this strategy (Table 2). When genes were ranked by fold change (Table 2), FosB was at the top of the list of genes, in agreement with previous reports showing that the induction of FosB was associated with ERK activation in 6-OHDAlesioned mice (Pavón et al., 2006).

\section{Genes associated with AIMs}

Our final goal was to identify genes involved in the early development of LID. Gene expression differs dramatically after one or repeated administrations of L-DOPA (Cenci and Konradi, 2010) and AIMs progressively increase in intensity after repeated administration of L-DOPA (Lundblad et al., 2005; Putterman et al., 2007; Nadjar et al., 2009; Francardo et al., 2011). The final score of AIMs obtained in mice injected with 6-OHDA in the striatum is usually variable, leading to the ability to distinguish highly and weakly dyskinetic animals (Lundblad et al., 2004) referred to below as high dyskinetic (HD) and low dyskinetic (LD). To study early gene expression changes associated with the development of 
Table 2. List of genes deregulated by L-DOPA and blocked by SL-327

\begin{tabular}{|c|c|c|c|c|c|}
\hline official gene symbol & Nucleotide universal identifier & L-DOPA vs saline (fold change) & L-DOPA + SL327 vs L-DOPA + vehicle (fold change) & Univariate $p$-value ${ }^{*}$ & $\overline{\mathrm{FDR}^{*}}$ \\
\hline FosB & Ere3vD30.tqh0Q.x94 & +8.76 & -2.08 & 0.0075 & 0.021 \\
\hline Arc & oyruyspXqhyohXojdA & +4.49 & -1.56 & 0.0196 & 0.036 \\
\hline Nptx2 & BU2LP1VoHoj2ptP6ec & +4.09 & -1.87 & 0.0066 & 0.020 \\
\hline Dgki & ZnFK.QqcS07EEoRjJU & +3.69 & -1.22 & 0.0325 & 0.048 \\
\hline Nedd4l & ESdC5ZVdFID3Qevluw & +3.21 & -1.34 & 0.0003 & 0.003 \\
\hline Car12 & re1dJUylHuMPt50k.U & +2.84 & -1.25 & 0.0020 & 0.010 \\
\hline Ippk & idenpHiD3Gq0Ugu5ek & +2.43 & -1.37 & $5.29 \mathrm{E}-05$ & 0.002 \\
\hline Th & Ko4nkRXhUJHi5TycDk & +2.32 & -1.40 & 0.0290 & 0.046 \\
\hline Dmkn & 3аkQXрееСбес0.6уBPU & +2.20 & -1.36 & 0.0049 & 0.018 \\
\hline Dmkn & Nmh10Y0RErfSov4e18 & +2.03 & -1.33 & 0.0040 & 0.016 \\
\hline Kcnk1 & 6VF0RwJE0ktVd1XgSM & +1.66 & -1.20 & 0.0002 & 0.003 \\
\hline Agpat1 & NI5Q.efVXJdFXIUrLo & +1.62 & -1.23 & 0.0315 & 0.048 \\
\hline $\mathrm{Bbc3}$ & uioaVJewjHsTkeeyMw & -2.30 & +1.36 & 0.0155 & 0.032 \\
\hline Ganc & 3qeocgyRKj6R_3ykYU & -2.26 & +1.26 & 0.0003 & 0.003 \\
\hline Hecw1 & 3Te09EhFExAnkiRjrk & -2.17 & +1.63 & 0.0013 & 0.008 \\
\hline Arrb2 & fladaeCo0Cjjh7jhS8 & -2.12 & +1.23 & 0.0016 & 0.009 \\
\hline Cln6 & Ed_ISRN0I4N3RReXrk & -2.07 & +1.32 & 0.0188 & 0.036 \\
\hline Syt12 & TrSLz4qjZNMbiuentE & -1.92 & +1.22 & 0.0057 & 0.019 \\
\hline Tusc1 & HpdSI3.yLN94Su0P4k & -1.76 & +1.27 & 0.0122 & 0.029 \\
\hline Vstm2a & 3.EkJQ07FbNLDvRTn4 & -1.58 & +1.22 & 0.0102 & 0.026 \\
\hline 3632451006Rik & oPE5K3u7N_TwP9SXfs & -1.38 & +1.22 & 0.0160 & 0.032 \\
\hline
\end{tabular}

List of the 28 probes deregulated by L-DOPA (our first experiment, 709 probes) for which SL327 pretreatment significantly reduced the effects of $\mathrm{L}-\mathrm{DOPA}$ (that could be increase or decrease) $(>1.2$-fold, $p<0.05$, FDR $<0.1)$. The fold changes of expression induced $3 \mathrm{~h}$ after L-DOPA in the first experiment (compared with T0, left column) and $3 \mathrm{~h}$ after L-DOPA + SL327 (compared with L-DOPA + vehicle, right column) are presented.

${ }^{*} p$-values and FDR values for the comparison of gene expression between L-DOPA + SL327 and L-DOPA + vehicle.

a HD score, we investigated whether it would be possible to predict at the very beginning of the treatment which mice will later develop high scores of AIMs. We treated 6-OHDA-lesioned mice with a daily injection of L-DOPA for $9 \mathrm{~d}$ and observed a strong correlation of AIM scores between days 2 and $9\left(r^{2}=0.84, p<\right.$ 0.0001; Fig. 4A). We therefore considered the AIM score after the second administration of L-DOPA as a good predictor of future LID development. Other groups of mice were then treated with 2 injections of L-DOPA (20 mg/kg, $n=18)$ or vehicle $(n=7)$ separated by a $24 \mathrm{~h}$ interval. At day 2 , AIMs were assessed during $2 \mathrm{~h}$ after L-DOPA treatment and mice were killed $1 \mathrm{~h}$ later. The mice treated with L-DOPA were then segregated according to their AIM score to compare the two extreme quartiles (HD mice, $n=4$; LD mice, $n=5$ ). The score of AIMs (ALO score) in the LD group was $8.6 \pm 5.9$ vs $36.3 \pm 8.7$ in the HD group $(p<0.05$; Fig. $4 B)$. The differences observed in AIM score were unlikely to be due to differences related to the lesion's extent because the limb use asymmetry measured by the cylinder test, the L-DOPA-induced rotation, and the quantification of TH immunoblots in the striatum were similar between the HD and LD groups (Fig. 4B). We compared the expression of the 709 probes previously found to be deregulated by L-DOPA (our first experiment) between the LD and HD mice. We found 26 genes that were significantly different between these two groups (Fig. 4C, Table 3 ). As for the previous experiments, FosB was found in the top gene list: FosB expression was significantly higher in the striatum of HD than in LD mice, which is consistent with several previous reports (Pavón et al., 2006; Cao et al., 2010).
Genes deregulated by L-DOPA, dependent on ERK activation, and associated with AIMs

Finally, we considered genes induced by the first administration of L-DOPA (first experiment), blocked by SL327 pretreatment (second experiment), and differentially expressed between the HD and LD mice (third experiment) as those of particular interest. This intersect list was composed of five genes (Table 4): Nptx2, Nedd4l, FosB, Th, and Ccrn4l. Interestingly FosB, Th, and $N p t x 2$ have all been previously reported to be induced by stimulation of D1R in 6-OHDA-lesioned animals (Berke et al., 1998, Darmopil et al., 2008). FosB was already shown to be involved in LID (Andersson et al., 1999). In our experiments, FosB expression was increased 12-fold after the first administration of L-DOPA ( $1 \mathrm{~h}$; Table 1); its expression was decreased by $>2$-fold when SL327 was administrated before L-DOPA (Table 2); and its expression was 2-fold higher in HD mice compared with LD animals as soon as the second administration of L-DOPA (Table 3). We confirmed by quantitative RT-PCR the increase in FosB expression in the lesioned striatum after L-DOPA, its decrease after pretreatment with SL327 (2-way ANOVA, lesion effect: $F_{(1,36)}=39.0, p<0.001 ;$ SL327 effect $F_{(1,36)}=12.0, p<0.01$; interaction: $F_{(1,36)}=9.8, p<0.01$; Fig. $\left.5 A\right)$ and its higher expression level in HD animals (Kruskal-Wallis ANOVA, $H_{(2,13)}=$ 10.7, $p<0.01$; Fig. $5 B$ ). Th encodes TH, the enzyme transforming tyrosine into the precursor of dopamine, L-DOPA. In normal conditions, $\mathrm{TH}$ is quasi-exclusively expressed in brainstem noradrenergic and dopaminergic neurons. However, $\mathrm{TH}-$ immunoreactive neurons have been detected in the striatum after dopamine depletion in animals and parkinsonian patients (Huot 
A

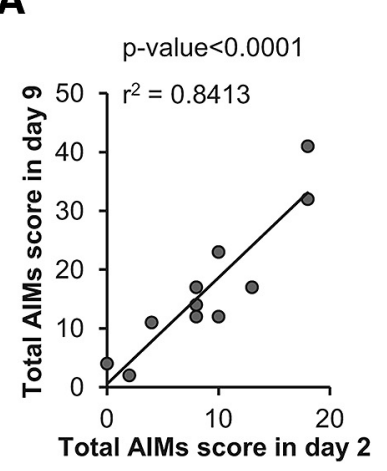

B

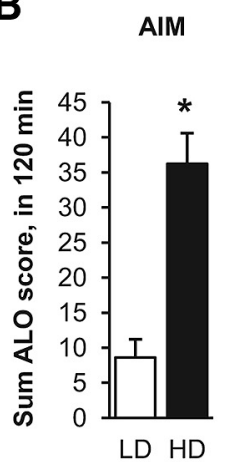

Rotation

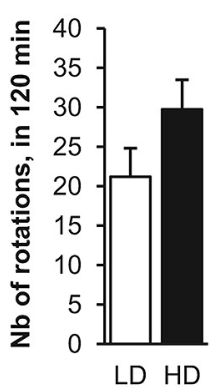

Cylinder test

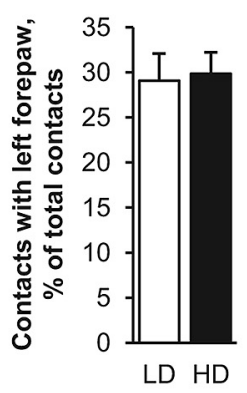

Lesion

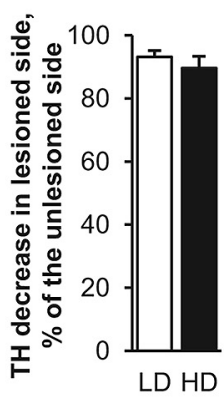

\section{C}

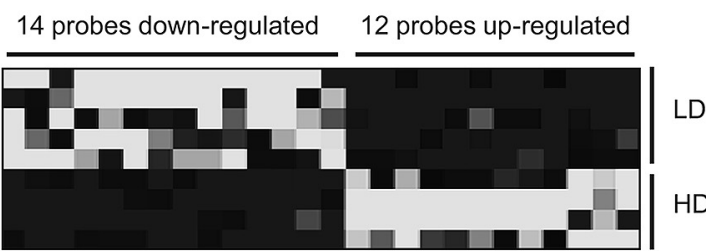

Probe intensity: Low

High

Figure 4. Gene expression signature associated with L-DOPA-induced dyskinesia. $A$, Correlation between AIM scores on days 2 and 9 of L-DOPA administration in the same mice. The second injection of $\mathrm{L}-\mathrm{DOPA}$ is highly predictive of the ability to develop AIMs, as evidenced by the high correlation between the total AIM score on days 2 and 9 of $\mathrm{L}-\mathrm{DOPA}$ administration (Spearman $r^{2}=$ $0.84, p<0.0001)$ performed on 11 lesioned mice. $\boldsymbol{B}$, Behavioral scores and quantifications of TH level reductions in HD and LD. Eighteen 6-OHDA-lesioned mice were tested for the limb use asymmetry by the cylinder test, treated with L-DOPA for 2 consecutive days, and scored for AL 0 dyskinesia and rotation for $2 \mathrm{~h}$ after a second L-DOPA injection. LD $(n=5)$ and HD $(n=4)$ mice were separated according to ALO scores (lowest and highest quartiles) and compared for the various parameters. Data are expressed as means + SEM. ${ }^{*} p<0.05$, HD versus LD. The number of L-DOPA-induced rotations, the limb use asymmetry measured by the cylinder test, and the dopaminergic denervation were not statistically different between the two groups, contrasting with their significant difference in L-DOPA-induced dyskinesia. C, Heat map of the 26 significantly deregulated probes (fold change $>1.2, p<0.05$ ) between HD and LD mice among the 709 probes found deregulated by an acute challenge of L-DOPA (Fig. 1). Hierarchical clustering of genes and samples was performed using one minus correlation metrics and average linkages with Biometric Research Branch array tools. The black probes correspond to downregulated genes and white probes correspond to upregulated genes.

et al., 2007). In our experiments, Th expression increased by $>3$-fold after L-DOPA ( $6 \mathrm{~h}$; Table 1 ), decreased by 1.4 -fold after SL327 (Table 2), and was 2-fold higher in HD than in LD animals (Table 3). These various effects on Th expression were confirmed by quantitative RT-PCR (2-way ANOVA, lesion effect: $F_{(1,31)}=$ 2.0, ns; SL327 effect: $F_{(1,31)}=8.6, p<0.01$, interaction: $F_{(1,31)}=$ $7.2, p<0.05$; Fig. $5 C$; Kruskal-Wallis ANOVA, $H_{(2,13)}=9.2, p<$ 0.01 ; Fig. $5 D$ ).

We next focused on Nptx 2 because it was the most statistically significant gene between HD and LD animals ( $p=0.0014$; Table 4). Nptx2 expression was increased by 4 -fold after acute treatment with L-DOPA, with a maximal upregulation at $3 \mathrm{~h}$ (Kruskal-Wallis ANOVA, $H_{(3,15)}=9.0, p<0.05$; Fig. 6A). This upregulation was repressed by SL327 pretreatment (2-way ANOVA, lesion effect: $F_{(1,39)}=34.8, p<0.001$; SL327 effect: $F_{(1,39)}=8.0, p<0.01$; interaction: $F_{(1,39)}=2.2, p<0.05$; Fig. $\left.6 B\right)$ and Nptx2 expression was 2 -fold higher in HD than in LD mice (Fig. 6C). Quantitative RT-PCR confirmed its increased expression by 4 -fold $3 \mathrm{~h}$ after L-DOPA in the dopamine-denervated striatum (mean relative expression values \pm SEM: T0 $(100 \pm 7)$, T1h (127 \pm 3$)$, T3h (383 \pm 34$)$, T6h (152 \pm 15$)$, Kruskal-Wallis ANOVA, $H_{(3,16)}=12.5, p<0.01$, posttest $p=0.003$ at $3 \mathrm{~h}$, data not shown). L-DOPA-induced Nptx2 expression was significantly reduced by SL327 pretreatment (2-way ANOVA, lesion effect: $F_{(1,36)}=8.5, p<0.001 ;$ SL327 effect: $F_{(1,36)}=5.4, p<0.05$; interaction: $F_{(1,36)}=2.2$, ns; Fig. $6 B$ ) and 2-fold higher in HD than in LD mice (Kruskal-Wallis ANOVA, $H_{(2,16)}=12.1, p<$ 0.01; Fig. 6C).
L-DOPA-induced dyskinesia are decreased in Narp KO mice Nptx2 is an IEG induced by D1R stimulation in the striatum of 6-OHDA-lesioned rats (Berke et al., 1998) and encodes a neuronal activity-regulated pentraxin, Narp (also known as neuronal pentraxin II; Tsui et al., 1996). We investigated the possible role of Narp in LID by examining AIM development in mutant mice in which the Nptx2 gene had been invalidated (Narp KO mice; Bjartmar et al., 2006). Narp KO mice have neither apparent neurological deficit nor brain dysfunction (Bjartmar et al., 2006). Spontaneous locomotor activity of Narp KO mice was reported previously to be similar to WT mice (Pacchioni and Kalivas, 2009). To confirm these results, NARP KO mice $(n=6)$ and WT littermates $(n=8)$ were placed in a circular corridor where spontaneous locomotor activity was assessed for $90 \mathrm{~min}$. The locomotor activity was not significantly different between genotypes ( $1 / 4$ turns during 90 min (mean \pm SEM): Narp KO $255 \pm 36$, WT mice $261 \pm 53$, Mann-Whitney test, ns). We first examined whether striatal proteins important for the signaling responses involved in LID generation were altered in Narp KO mice. Immunoblotting did not reveal any significant change in the striatal levels of G $\alpha$ olf, the G-protein subunit coupling D1R to adenylyl cyclase in the striatum, the regulatory protein DARPP-32, or ERK 1 and ERK2 in the mice with homozygous or heterozygous deletion of Narp gene (Kruskall-Wallis ANOVA, ns for Goolf, ERK1, ERK2, DARPP-32, and actin; $H_{(2,35)}=9.8, p<0.05$, for Narp; Fig. 7A). This suggested no gross alteration of the D1Rdependent signaling cascade proteins in Narp KO mice. To investigate the role of Narp in LID development, Narp KO mice and 
Table 3. LID signature: deregulated genes between high and low dyskinetic animals

\begin{tabular}{|c|c|c|c|c|c|c|}
\hline \multirow[b]{2}{*}{ Official gene symbol } & \multirow[b]{2}{*}{ Nucleotide universal identifier } & \multirow[b]{2}{*}{ Univariate $p$ value } & \multirow[b]{2}{*}{ FDR } & \multirow[b]{2}{*}{ HD/LD (fold change) } & \multicolumn{2}{|c|}{ Probe intensity } \\
\hline & & & & & LD & HD \\
\hline FosB & Ere3vD30.tqh0Q.x94 & 0.0052 & 0.06 & +2.09 & 905 & 1891 \\
\hline Nptx2 & BU2LP1VoHoj2ptP6ec & 0.0014 & 0.05 & +1.91 & 1016 & 1936 \\
\hline Tirap & 6kxeKn6PcXUkUUAQKI & 0.0373 & 0.16 & +1.43 & 23 & 34 \\
\hline Tac1 & HZWCFQ10kvf6PDq0mo & 0.0129 & 0.11 & +1.41 & 4634 & 6516 \\
\hline Car12 & $\mathrm{f} 2 \mathrm{X} 7 \mathrm{n} X w \mathrm{wd5bmK5Curlw}$ & 0.0103 & 0.11 & +1.33 & 384 & 511 \\
\hline Ece1 & 6PnSruSolCkolZlevl & 0.0304 & 0.15 & +1.23 & 483 & 593 \\
\hline Zfp281 & rsQiwIRUUIIvErCt2I & 0.0014 & 0.05 & +1.21 & 252 & 305 \\
\hline Nedd4I & ESdC5ZVdFID3Qevluw & 0.0051 & 0.06 & +1.21 & 1257 & 1518 \\
\hline Lingo3 & HVVh.VNExAePhKEYOE & 0.0480 & 0.17 & +1.20 & 171 & 205 \\
\hline Tmem106c & fVTEC48S.VWQq3Ngqc & 0.0363 & 0.16 & -1.20 & 276 & 230 \\
\hline Triobp & 6hH3fe9bi0VwfDAF9Y & 0.0022 & 0.05 & -1.21 & 241 & 199 \\
\hline Arhgap4 & Bpc_fRdJXfcrd_orJA & 0.0171 & 0.11 & -1.28 & 35 & 27 \\
\hline lgfbp5 & ZVY7ölnadd.JP_sfCg & 0.0474 & 0.17 & -1.35 & 1025 & 757 \\
\hline Rell1 & 97rl5L_04FRHpJy4fo & 0.0459 & 0.17 & -1.36 & 39 & 29 \\
\hline F11r & QdMHGeZ9lbdAfQUHac & 0.0332 & 0.15 & -1.37 & 30 & 22 \\
\hline Mapk11 & ipXv4AZvqrsGXV4IhA & 0.0151 & 0.11 & -1.37 & 64 & 46 \\
\hline Fam113a & ol6MpKN8r6JylxS6V4 & 0.0267 & 0.14 & -1.38 & 64 & 47 \\
\hline Metap1d & iqi6lx4UB5RCCXiDaU & 0.0204 & 0.11 & -1.40 & 41 & 30 \\
\hline
\end{tabular}

List of the 26 genes significantly different between HD and LD animals among the 709 genes found to be deregulated by acute L-DOPA in the striatum (our first experiment).

Table 4. Genes deregulated by L-DOPA associated with LID and dependent on ERK

\begin{tabular}{|c|c|c|c|c|c|}
\hline \multirow{2}{*}{$\begin{array}{l}\text { Official gene } \\
\text { symbol }\end{array}$} & \multirow{2}{*}{$\begin{array}{l}\text { Nucleotide universal } \\
\text { identifier }\end{array}$} & \multicolumn{2}{|c|}{$\begin{array}{l}\text { Probe } \\
\text { intensity }\end{array}$} & \multirow{2}{*}{$\begin{array}{l}\text { HD vs LD } \\
\text { (fold change) }\end{array}$} & \multirow{2}{*}{$\begin{array}{l}\text { Univariate } \\
p \text {-value }\end{array}$} \\
\hline & & LD & $H D$ & & \\
\hline Nptx2 & BU2LP1VoHoj2ptP6ec & 1016 & 1936 & +1.9 & 0.0014 \\
\hline Nedd4I & ESdC5ZVdFID3Qevluw & 1257 & 1518 & +1.2 & 0.0051 \\
\hline FosB & Ere3vD30.tqh0Q.x94 & 905 & 1891 & +2.1 & 0.0052 \\
\hline Th & Ko4nkRXhUJHi5TycDk & 86 & 152 & +1.8 & 0.0111 \\
\hline Ccrn4l & ruOG_shu4l8dQ0fdeo & 1524 & 1907 & +1.3 & 0.0458 \\
\hline
\end{tabular}

List of the five genes belonging to the acute L-DOPA signature (Table 1), the genes blocked by SL327 (Table 3), and the genes associated with dyskinesia (this table). Probe intensity in microarrays, fold change, and univariate $p$-values are provided comparing $H D$ versus $L D$ animals.

WT littermates were unilaterally injected with 6-OHDA into the striatum and chronically treated with L-DOPA using an escalating dose protocol $(5,10$, and $20 \mathrm{mg} / \mathrm{kg}$ i.p. daily for $5 \mathrm{~d}$ for each dose; Lundblad et al., 2004). The reduction in TH immunoreactivity in the striatum was similar in WT and Narp KO mice, showing that the lesion of dopamine neurons was comparable in the two groups of mice (2-way ANOVA, lesion effect: $F_{(1,66)}=$ 65.34, $p<0.001$; genotype effect: $F_{(1,66)}=0.85$, ns; interaction, $F_{(1,66)}=0.09$, ns; Fig. $\left.7 B\right)$. We then compared AIMs in mutant and WT mice. We observed a significant decrease in AIM score in Narp KO mice compared with WT mice throughout the escalating doses (2-way repeated-measures ANOVA, genotype effect: $F_{(1,36)}=4.13, p<0.05$; dose effect: $F_{(2,72)}=49.84, p<0.001$; interaction: $F_{(2,72)}=1.39$, ns; Fig. $\left.7 C\right)$. Post hoc analysis found a significantly decreased score in the mutant mice at the end of the trial at $20 \mathrm{mg} / \mathrm{kg} \mathrm{L-DOPA}$ (Newman-Keuls, $p<0.05$; Fig. $7 C)$. At this dose, the time course of L-DOPA effects on AIMs indicated that the reduction was present throughout the period of action of L-DOPA (2-way repeated-measures ANOVA, genotype effect: $F_{(1,36)}=6.17, p<0.05$; time effect: $F_{(5,180)}=$ 19.23, $p<0.001$; interaction: $F_{(5,180)}=2.32, p<0.05$; Fig. $7 D)$. These results indicated that Narp is implicated in the development of AIMs induced by L-DOPA in unilaterally 6-OHDA lesioned mice.

\section{Nptx2 in the striatum is involved in the development of L-DOPA-induced dyskinesia}

To investigate whether Narp secretion in the striatum is involved in the development of LID, we used a mutant form of Narp that blocks secretion of WT Narp (Narp-N13) and a mutant that does not block secretion of WT Narp (Narp-N; O'Brien et al., 2002). In HEK293 cells, Narp-N13 prevented its secretion and reduced secretion of coexpressed WT Narp (Fig. 8A). Narp-N13 prevented expression of WT Narp on the cell surface of HEK293 cells (Fig. $8 B$ ). Narp-N did not prevent secretion of coexpressed WT Narp (Fig. 8A). WT mice were then injected in the dorsal striatum, concomitantly to 6-OHDA, with a recombinant AAV expressing Narp-N13 (AAV-DN13), Narp-N (AAV-Narp-N), or the green fluorescent protein (AAV-eGFP). Mice were chronically treated with L-DOPA using the same escalating dose protocol as for Narp $\mathrm{KO}$ mice. The reduction in TH immunoreactivity in the striatum was similar in all groups of mice (2-way ANOVA, lesion effect: $F_{(1,18)}=60.7, p<0.001$; group effect: $F_{(2,18)}=0.5$, ns; interaction: $F_{(2,18)}=0.17$, ns; Fig. $\left.8 C\right)$. Mice injected with AAV-DN13 had a dramatic decrease of AIMs score compared with those injected with AAV-eGFP (2-way ANOVA, AAV effect: $F_{(1,12)}=8.2$, $p<0.01$; dose effect: $F_{(2,24)}=18.7, p<0.001$; interaction: $\left.F_{(2,24)}=8.4, p<0.01\right)$ or AAV-Narp-N (2-way ANOVA, AAV effect: $F_{(1,12)}=5.9, p<0.05$; dose effect: $F_{(2,24)}=6.7, p<0.01$; interaction: $F_{(2,24)}=2.2$, ns; Fig. $\left.8 D\right)$. At $20 \mathrm{mg} / \mathrm{kg}$, AIM scores were significantly different for AAV-DN13 compared with AAV-eGFP (2-way repeated-measures ANOVA, AAV effect: $F_{(1,12)}=4.5, p<$ 0.05 ; time effect: $F_{(4,48)}=4.5, p<0.05$; interaction: $F_{(4,48)}=3.8, p<$ 0.01 ) or to AAV-Narp-N (2-way repeated-measures ANOVA, $F_{(1,12)}=$ $4.9, p<0.05$; time effect: $F_{(4,48)}=1.8$, ns; interaction: $F_{(4,48)}=1.5$, ns; Fig. $8 E$ ). Mice injected with the AAV-Narp-N were not significantly 
A

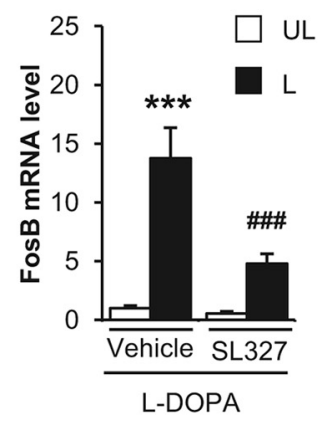

B

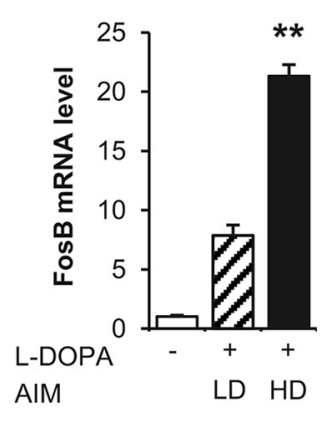

C

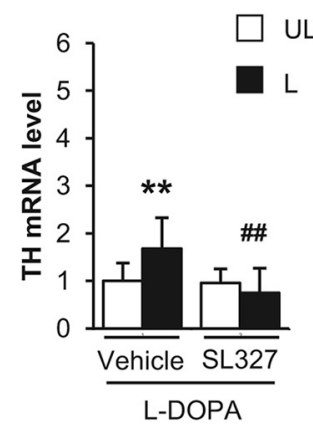

D

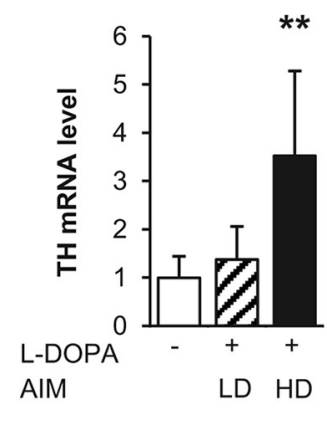

Figure 5. Quantitative RT-PCR indicates high expression of Fos $B$ and Th genes in dyskinetic animals. Relative expression of Fos $B(\boldsymbol{A}, \boldsymbol{B})$, and TH $(\boldsymbol{C}, \boldsymbol{D})$ assessed by independent quantitative RT-PCR from striata of 6-OHDA-lesioned mice. In a first experiment $(\boldsymbol{A}, \boldsymbol{C})$, total mRNA was extracted from the lesioned (L) and the unlesioned (UL) striatum of mice treated with 20 mg/kg L-D0PA and pretreated with $50 \mathrm{mg} / \mathrm{kg} \mathrm{SL327}$ or vehicle $30 \mathrm{~min}$ before L-DOPA ( $n=8-9$ per group). Mice were killed $3 \mathrm{~h}$ after L-DOPA treatment. In a second experiment ( $\boldsymbol{B}, \boldsymbol{D})$, total $\mathrm{mRNA}$ was extracted from the 6-0HDA-lesioned striatum of LD $(n=5)$ and HD $(n=4)$ mice (as defined in the Materials and Methods), as well as saline-treated animals (white boxes, $n=5)$. Each reverse transcription was performed in triplicate. The relative levels of mRNA were standardized using $36 \mathrm{~b} 4$ ribosomal RNA as the nonvariant RNA. Expression values were determined using the $\Delta \Delta C \mathrm{CT}$ method. Data are expressed as mean fold change + SEM compared with the means in vehicle-L-DOPA unlesioned striata $(\boldsymbol{A}, \boldsymbol{C})$ or saline lesioned striata $(\boldsymbol{B}, \boldsymbol{D})$. Post hoc tests: $\boldsymbol{A}$ : ${ }^{* * *} p<0.001$, lesioned versus unlesioned side, \#\#\# $p<0.001$, SL327 versus vehicle; $\boldsymbol{B},{ }^{* *} p<0.01$ HD versus saline; $\boldsymbol{C}:{ }^{* *} p<0.01$, lesioned versus unlesioned side, \#\# $p<0.01$, SL327 versus vehicle; $\boldsymbol{D}$ : $p<0.01,{ }^{* *} p<0.01$ versus saline.

different from those injected with AAV-eGFP. Together, these results demonstrate that Narp secretion in the striatum is necessary for the LID development.

\section{Discussion}

Using an unbiased transcriptomic approach taking into account the time course of the effects, we identified a detailed gene expression signature induced by the first injection of L-DOPA in the striatum of unilaterally 6-OHDA-lesioned mice. We subsequently restricted this signature to genes in which deregulation was prevented by a MEK inhibitor, SL327. Finally, among those genes, we identified five that were associated with early LID development, FosB, Th, Nptx2, Ccrn4l, and Nedd4l. We focused on Nptx2, which encodes Narp, a protein regulating synaptic plasticity (Xu et al., 2003). We show that Nptx2 is an important factor in LID development by demonstrating that AIMs induced by a chronic treatment with L-DOPA in 6-OHDA-lesioned mice are decreased in Narp KO mice or by striatal expression of a dominant-negative mutant of Narp.

Gene expression analysis in the dopamine-depleted striatum highlighted a complex transcriptional response to acute L-DOPA administration. Our gene ontology analysis supports previous suggestions that L-DOPA changes corticostriatal synaptic plasticity homeostasis (Calabresi et al., 2000; Calon et al., 2000; Picconi et al., 2003), which results from the successive regulation of IEGs followed by a longer-lasting gene expression response (El AtifiBorel et al., 2009; Cenci and Konradi, 2010). We found that L-DOPA regulates multiple catalytic and regulatory components of the D1R/PKA/DARPP-32/ERK cascades, which are thought to be implicated in LID development (Santini et al., 2007; Bateup et al., 2010). Overall, our results suggest that L-DOPA-induced gene expression in the striatum results in a rapid and profound downregulation of these cascades followed by a slow progressive return to basal level. This regulation is in agreement with the progressive decrease in L-DOPA-induced ERK phosphorylation and IEG production in the dopamine-denervated striatum after prolonged chronic treatment (Santini et al., 2007; Cenci and Konradi, 2010; Ding et al., 2011). Alterations of protein phosphatases at the mRNA level have been previously reported after dopamine depletion in rats by Meurers et al. (2009) who proposed that dopaminergic denervation resulted in "prodopaminergic phos- phorylation" patterns. Our present results suggest that L-DOPA counteracts this state by producing a strong negative feedback on dopamine signaling. Together, these data indicate that dopamine regulates PKA/DARPP-32/ERK cascades through changes in protein phosphatase expression, resulting in their sensitization after dopamine depletion and their downregulation after treatment with L-DOPA. The mechanisms by which dopamine regulates the expression of protein phosphatases remain to be explored. None of these genes was significantly blocked by SL327 pretreatment in our experiments, suggesting an ERK-independent pathway.

D1R/PKA-mediated activation of ERK signaling after dopamine depletion has been suggested to play a major role in AIM development (Gerfen et al., 2002; Picconi et al., 2003; Santini et al., 2007; Westin et al., 2007; Schuster et al., 2008; Darmopil et al., 2009; Lindgren et al., 2009; Santini et al., 2009a; Santini et al., 2009b; Lebel et al., 2010; Santini et al., 2010; Francardo et al., 2011). The role of DARPP-32 in ERK activation by L-DOPA is debated because ERK phosphorylation was decreased in DARPP-32 KO mice in one study (Santini et al., 2007), but not in another one (Gerfen et al., 2008). A recent report using conditional KO of DARPP-32 in D1 MSN or a knock in mutation preventing phosphorylation of DARPP-32 by PKA support the role of DARPP-32 (Santini et al., 2012) and that LID is attenuated either by DARPP-32 general or conditional mutation (Santini et al., 2007, 2012, Bateup et al., 2010) or by blockade of ERK activation (Santini et al., 2007, Fasano et al., 2010). LID is proposed to result from a maladaptive plasticity of striatal neurons and longterm cellular alterations produced by the intense activation of ERK-dependent signaling pathways after the first L-DOPA treatments (Cenci and Konradi, 2010), whereas ERK activation ends to decrease in MSNs with repeated drug administration (Santini et al., 2007; Ding et al., 2011). In rats, only a few of the genes regulated after acute L-DOPA administration overlapped with those expressed after chronic exposure (El Atifi-Borel et al., 2009). By focusing on genes induced by the first administrations of L-DOPA, blocked by the MEK inhibitor SL327, and associated with the early development of AIMs, we postulated that we would be able to identify candidates involved in LID induction. Among the 5 genes identified by this approach, FosB was previously shown to be induced by L-DOPA and associated with dyskinesia 
A

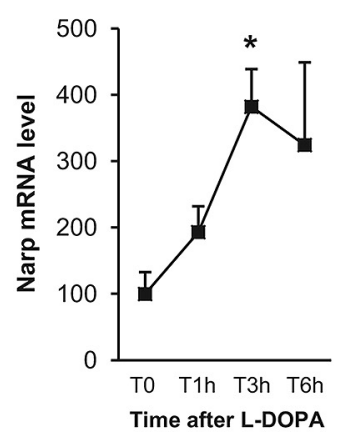

B

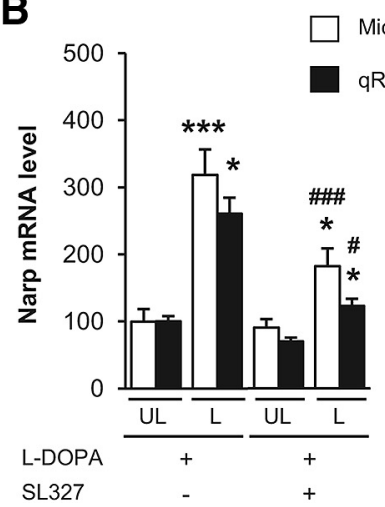

C

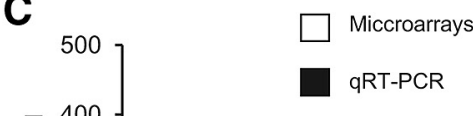

Figure 6. Increased expression of Nptx2 in dyskinetic mice. A, Time course of Nptx2 deregulation as assessed by expression values in microarray experiments 1,3 , and $6 \mathrm{~h}$ after an acute administration of $20 \mathrm{mg} / \mathrm{kg} \mathrm{L-DOPA}$ in the 6-OHDA-lesioned striatum. Data correspond to percentage of the mean of T0 samples and are expressed as mean + SEM (T0, $n=3 ; \mathrm{T} 1 \mathrm{~h}, n=4 ; \mathrm{T} 3 \mathrm{~h}, n=$ $5 ;$ T6h, $n=3$ ). Nptx2 was significantly induced by L-DOPA. ${ }^{*} p<0.05$, post hoc test. $\boldsymbol{B}$, Effect of the MEK inhibitor (SL327) on the expression of Nptx2 in microarray experiments (white boxes) and quantitative RT-PCR (black boxes). Total mRNA was extracted from the lesioned (L) and the unlesioned (UL) striatum $3 \mathrm{~h}$ after treatment with $20 \mathrm{mg} / \mathrm{kg} \mathrm{L-DOPA}$ and pretreatment with $50 \mathrm{mg} / \mathrm{kg}$ SL327 or vehicle 30 min before L-DOPA ( $n=10-11$ per group). Data were normalized on unlesioned group treated with vehicle. Data are expressed as mean + SEM. ${ }^{* * *} p<0.001,{ }^{*} p<0.05$, lesioned versus unlesioned, \#\#\# $p<0.001, \# p<0.05$, SL327 versus Vehicle, post hoc test. C, Nptx2 expression in LD and HD mice after 2 injections of L-D0PA in 6-0HDA lesioned mice. Microarrays (white boxes) and quantitative RT-PCR (black boxes) expression values were obtained as detailed above from total mRNA extracted from the 6-0HDA-lesioned striatum of LD ( $n=5)$, HD $(n=4)$, and saline-treated mice $(n=7)$. Data were normalized on saline-treated mice and are expressed as mean + SEM. ${ }^{* *} p<0.01$ versus saline, post hoc test.
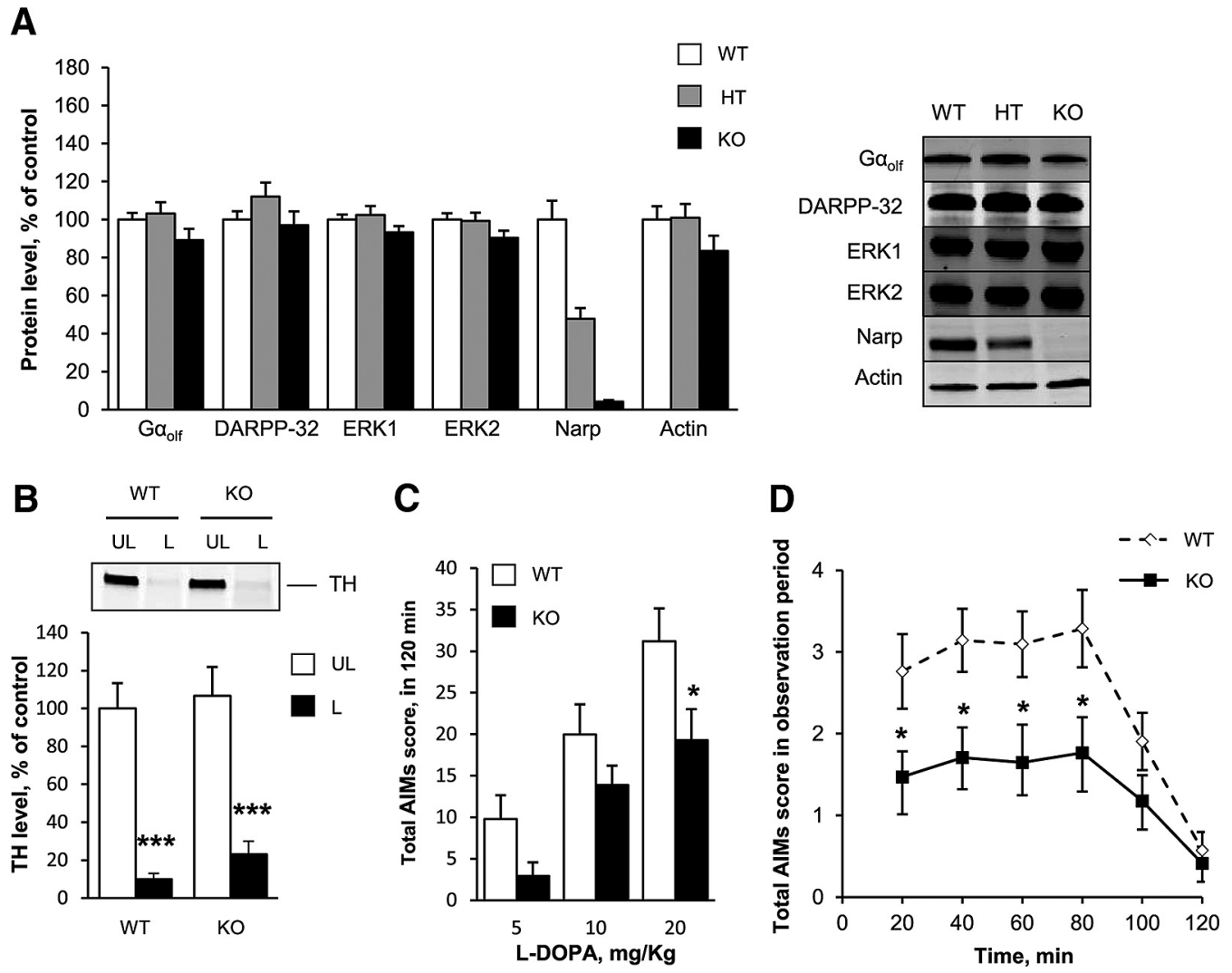

Figure 7. Reduction of L-DOPA-induced dyskinesia in Narp KO mice. A, Protein levels of DARPP-32, $G \alpha_{\text {olf }}$ ERK1/2, Narp, and actin assessed by immunoblotting in the striatum of WT mice $(n=12)$, homozygous (KO, $n=11$ ), and heterozygous (HT, $n=12$ ) Narp KO mice. A representative immunoblot (right) is presented. The protein levels of DARPP-32, G $\alpha_{\text {olf }}$ ERK1/2 and actin (left) were not significantly different between genotypes. Data were normalized on WT mice and correspond to the mean + SEM. $\boldsymbol{B}$, Comparison of dopamine neuron lesion in Narp KO and WT 6-OHDA-lesioned mice. Dopaminergic fiber lesion was assessed by determining the striatal levels of TH by immunoblotting in the lesioned (L) and unlesioned (UL) striatum of the WT $(n=21)$ and Narp KO $(n=17)$ mice, previously scored for AIMs. A comparable degree of dopamine denervation was observed in both groups. Data are expressed as means + SEM of percentage of the mean in the unlesioned striata (control). ${ }^{* * *} p<0.001$, lesioned versus unlesioned side, post hoc test. C, Total AIM score obtained after each period of treatment with L-DOPA at 5,10 , and $20 \mathrm{mg} / \mathrm{kg}$ (see Materials and Methods) in 6-OHDA-lesioned WT mice (white boxes, $n=17$ ) and Narp K0 mice (black boxes, $n=21$ ). Total AIM scores are the sum of scores obtained every $20 \mathrm{~min}$ for $2 \mathrm{~h}$ after L-DOPA treatment. Data are expressed as means + SEM. ${ }^{*} p<0.05, \mathrm{KO}$ versus WT, post hoc test. D, Time course of AIM score after L-DOPA ( $20 \mathrm{mg} / \mathrm{kg}$ on day 15 of treatment; see Materials and Methods) in WT mice (white boxes, $n=21$ ) and Narp KO mice (black boxes, $n=27)$. Data are expressed as means \pm SEM. ${ }^{*} p<0.05$, KO versus WT, post hoc test. 


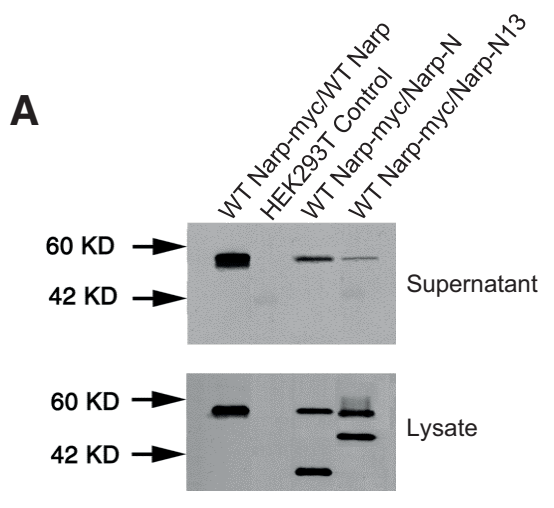

C

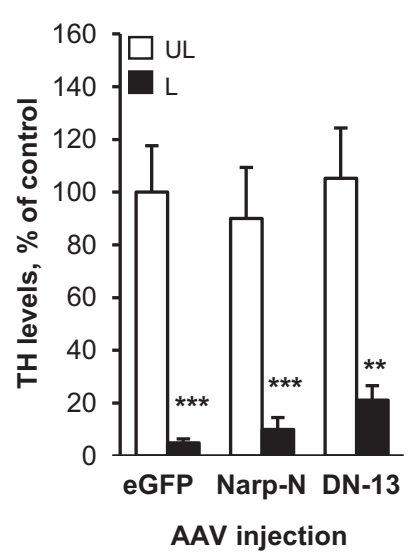

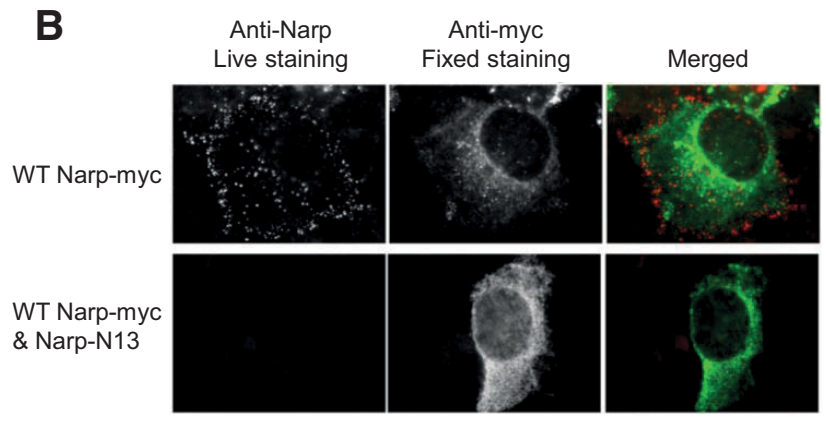

E

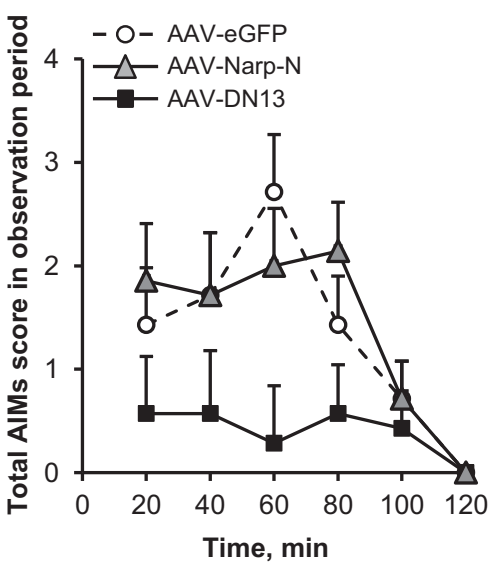

Figure 8. L-DOPA-induced dyskinesia in mice injected with AAV-Narp-N, AAV-DN13, or AAV-GFP in the striatum. Narp deletion constructs act as dominant negatives for secretion of WT Narp. $A$, Narp constructs were expressed in combination with WT Narp in HEK293 cells and, after $48 \mathrm{~h}$, Narp proteins were examined by Western blot using Narp antibody in supernatant and cell lysate. Mutation within the pentraxin domain (Narp-N13; $\Delta 345-416)$ prevents its secretion and reduces secretion of coexpressed WT Narp (lane 4). Complete deletion of the pentraxin domain (Narp-N; $\Delta$ 191-410) did not prevent secretion of coexpressed WT Narp (lane 3). $\boldsymbol{B}$, Narp-N13 prevents expression of WT Narp on the cell surface of HEK293 cells. Cells expressing the indicated constructs were live labeled with Narp antibody and then fixed and permeabilized and labeled with myc antibody to confirm intracellular expression of WT Narp-myc. $\boldsymbol{C}-\boldsymbol{E}$, Comparison of mice injected in the striatum with an AAV containing the dominant-negative Narp-N13 (AAV-DN13, $n=7$ ), Narp-N (AAV-Narp-N, $n=7$ ), or the green fluorescent protein (AAV-eGFP, $n=7$ ). C, Dopamine fiber lesion was assessed by determining the striatal levels of TH by immunoblotting in the lesioned (L) and unlesioned (UL) striatum. Values are means + SEM. ${ }^{* * *} p<0.001,{ }^{* *} p<0.01, \mathrm{~L}$ versus $\mathrm{UL}$ side, $p$ ost hoc Newman-Keuls test. D, Total AIMs score obtained after each period of treatment with L-DOPA at 5, 10, and $20 \mathrm{mg} / \mathrm{kg}$. Total AIMs scores are the sum of scores obtained every $20 \mathrm{~min}$ for $2 \mathrm{~h}$ after L-DOPA. Data are means + SEM. * $p<0.05$, AAV-DN13 versus AAV-GFP, \#p $<0.05$ AAV-DN13 versus AAV-Narp-N, post hoc Newman-Keuls test. E, Time course of AIMs score after L-D0PA at 20 $\mathrm{mg} / \mathrm{kg}$ (day 15). Values are means \pm SEM.

(Andersson et al., 1999; Cenci et al., 1999; Heiman et al., 2014). Several lines of evidence support the role in LID of $\Delta$ FosB, a well characterized splice variant product of the $F o s B$ gene coding for a truncated stable protein. Overexpression of $\Delta$ FosB in the dopamine-denervated striatum reproduced abnormal movements when associated with L-DOPA (Cao et al., 2010), whereas overexpression of $\Delta \mathrm{JunD}$, a truncated form of JunD, acting as a dominant-negative form of $\Delta$ FosB decreased established LID in monkey (Berton et al., 2009). The second gene in our list, Th, encodes TH, the enzyme that converts tyrosine into L-DOPA. At first glance, this result may seem surprising because, in the striatum, TH protein levels are dramatically reduced after lesion of dopaminergic terminals. However, previous experiments identified a population of $\mathrm{TH}$-positive neurons in the dopaminedepleted mouse striatum, which increased after L-DOPA treatment (Darmopil et al., 2008). These neurons corresponded to MSNs, in agreement with previous observations (Tashiro et al., 1989) and with a recent study showing increased TH mRNA in D1R-expressing MSNs (Heiman et al., 2014). The number of striatal TH-positive neurons correlates with the level of FosB and with the severity of LID in hemiparkinsonian mice (Francardo et al., 2011; Heiman et al., 2014). Our results suggest that TH expression in striatal neurons is regulated in an ERK-dependent manner and may be implicated in the occurrence of LID. Nedd4l encodes an E3 ubiquitin protein ligase that mediates the ubiquitination of multiple target substrates (Harvey and Kumar, 1999). Interestingly, recent findings suggest that L-DOPA impairs ubiquitin-proteasome activity in parkinsonism through D1R and may contribute to LID development (Berthet et al., 2012). Ccrn4l (CCR4 carbon catabolite repression 4-like) codes for nocturnin, a circadian deadenylase that confers resistance to diet-induced obesity (Green et al., 2007) and the function of which in the brain is not characterized. Interestingly, a recent study found that $T h$, Nedd4l, Ccrn4l, Nptx2, and FosB genes are deregulated preferentially in the D1R-expressing MSNs by chronic L-DOPA treatment (Heiman et al., 2014).

We focused on Nptx2, the most significantly differently expressed gene between highly and weakly dyskinetic mice after FosB. We found that AIMs generated by chronic administration of L-DOPA were significantly reduced in Narp KO mice, making it a prime candidate for the generation of LID. Moreover, expression of a dominant-negative form of Narp dramatically improved 
LID in lesioned WT mice. Nptx2 encodes Narp, a member of the neuronal pentraxin family also including neuronal pentraxin 1 (NP1) and the neuronal pentraxin receptor (NPR). Nptx2 is an IEG induced by neuronal activation (Tsui et al., 1996) and by D1R stimulation in the striatum of 6-OHDA-lesioned rats (Berke et al., 1998). Narp is a secreted protein that binds to the extracellular surface of AMPARs and regulates their synaptic clustering (O'Brien et al., 2002). In the hippocampus, Narp is enriched at excitatory synapses on parvalbumin interneurons (Chang et al., 2010). Narp and NP1 enhance glutamate signaling by clustering AMPA receptors and NPR mediates endocytosis of surface AMPARs during mGluR1-dependent LTD (Cho et al., 2008). Considering its crucial role in the homeostasis of synaptic plasticity, Narp overexpression after L-DOPA treatment may play a role in LID development by promoting abnormal plasticity of corticostriatal synapses through postsynaptic AMPAR clustering (Kobylecki et al., 2010) and may participate in ERK-dependent dysregulation of striatal synaptic plasticity (Cerovic et al., 2014). Our experiments showing decreased LID intensity in Narp KO mice or after expression of a dominant-negative form of Narp in the striatum support this hypothesis. Interestingly, increased Narp mRNA levels have been reported in the prefrontal cortex and substantia nigra of PD patients, with increased Narp immunoreactivity in Lewy bodies (Moran et al., 2008). Although the relevance of these findings for the development of LID remains to be determined, they may indicate a particular reactivity of Narp expression after dopamine depletion. Narp has also been found to play a role in long-term behavioral alterations associated with chronic stimulation of dopamine transmission, such as cocaineinduced behaviors (Pacchioni, 2009a,2009b). It will be important in future studies to determine how Narp, and possibly other neuronal pentraxin family members, regulate the stability of synaptic plasticity that underlies rapid and long-lasting changes in behavior related to dopamine depletion and L-DOPA therapy.

Our results confirm that a major effect of L-DOPA in the dopamine-depleted striatum is the induction of a molecular signature corresponding to intracellular signaling cascades regulating synaptic plasticity. The acute administration of L-DOPA regulates genes encoding positive and negative regulators of the D1R/PKA/DARPP-32/ERK cascades that most likely result in a global negative feedback, which may explain its progressive downregulation after repeated administration. We identified Narp as a candidate for the early development of LID, suggesting that the homeostasis of glutamate receptors at corticostriatal and/or thalamostriatal synapses is an important element of the maladaptive plasticity that leads to LID. Although extrapolation to human pathology has to be very cautious due to the intrinsic limitation of the animal model used in this study, early molecular events induced during the "induction" phase of L-DOPA treatment, such as Narp secretion, could be attractive targets for therapeutic intervention aimed at preventing LID occurrence in patients with PD.

\section{References}

Alcacer C, Santini E, Valjent E, Gaven F, Girault JA, Hervé D (2012) G $\alpha$ (olf) mutation allows parsing the role of cAMP-dependent and extracellular signalregulated kinase-dependent signaling in L-3,4-dihydroxyphenylalanine-induced dyskinesia. J Neurosci 32:5900-5910. CrossRef Medline

Andersson M, Hilbertson A, Cenci MA (1999) Striatal fosB expression is causally linked with 1-DOPA-induced abnormal involuntary movements and the associated upregulation of striatal prodynorphin mRNA in a rat model of Parkinson's disease. Neurobiol Dis 6:461-474. CrossRef Medline

Andersson M, Westin JE, Cenci MA (2003) Time course of striatal DeltaFosB-like immunoreactivity and prodynorphin mRNA levels after discontinuation of chronic dopaminomimetic treatment. Eur J Neurosci 17:661-666. CrossRef Medline

Aubert I, Guigoni C, Håkansson K, Li Q, Dovero S, Barthe N, Bioulac BH, Gross CE, Fisone G, Bloch B, Bezard E (2005) Increased D1 dopamine receptor signaling in levodopa-induced dyskinesia. Ann Neurol 57:17-26. CrossRef Medline

Bateup HS, Santini E, Shen W, Birnbaum S, Valjent E, Surmeier DJ, Fisone G, Nestler EJ, Greengard P (2010) Distinct subclasses of medium spiny neurons differentially regulate striatal motor behaviors. Proc Natl Acad Sci U S A 107:14845-14850. CrossRef Medline

Berke JD, Paletzki RF, Aronson GJ, Hyman SE, Gerfen CR (1998) A complex program of striatal gene expression induced by dopaminergic stimulation. J Neurosci 18:5301-5310. Medline

Berthet A, Bezard E, Porras G, Fasano S, Barroso-Chinea P, Dehay B, Martinez A, Thiolat ML, Nosten-Bertrand M, Giros B, Baufreton J, Li Q, Bloch B, Martin-Negrier ML (2012) L-DOPA impairs proteasome activity in parkinsonism through D1 dopamine receptor. J Neurosci 32:681-691. CrossRef Medline

Berton O, Guigoni C, Li Q, Bioulac BH, Aubert I, Gross CE, Dileone RJ, Nestler EJ, Bezard E (2009) Striatal overexpression of DeltaJunD resets L-DOPA-induced dyskinesia in a primate model of Parkinson disease. Biol Psychiatry 66:554-561. CrossRef Medline

Bjartmar L, Huberman AD, Ullian EM, Rentería RC, Liu X, Xu W, Prezioso J, Susman MW, Stellwagen D, Stokes CC, Cho R, Worley P, Malenka RC, Ball S, Peachey NS, Copenhagen D, Chapman B, Nakamoto M, Barres BA, Perin MS (2006) Neuronal pentraxins mediate synaptic refinement in the developing visual system. J Neurosci 26:6269-6281. CrossRef Medline

Calabresi P, Gubellini P, Centonze D, Picconi B, Bernardi G, Chergui K, Svenningsson P, Fienberg AA, Greengard P (2000) Dopamine and cAMP-regulated phosphoprotein $32 \mathrm{kDa}$ controls both striatal long-term depression and long-term potentiation, opposing forms of synaptic plasticity. J Neurosci 20:8443-8451. Medline

Calabresi P, Picconi B, Tozzi A, Di Filippo M (2007) Dopamine-mediated regulation of corticostriatal synaptic plasticity. Trends Neurosci 30:211219. CrossRef Medline

Calon F, Hadj Tahar A, Blanchet PJ, Morissette M, Grondin R, Goulet M, Doucet JP, Robertson GS, Nestler E, Di Paolo T, Bédard PJ (2000) Dopamine-receptor stimulation: biobehavioral and biochemical consequences. Trends Neurosci 23:S92-S100. CrossRef Medline

Cao X, Yasuda T, Uthayathas S, Watts RL, Mouradian MM, Mochizuki H, Papa SM (2010) Striatal overexpression of DeltaFosB reproduces chronic levodopa-induced involuntary movements. J Neurosci 30:73357343. CrossRef Medline

Cenci MA, Konradi C (2010) Maladaptive striatal plasticity in L-DOPAinduced dyskinesia. Prog Brain Res 183:209-233. CrossRef Medline

Cenci MA, Tranberg A, Andersson M, Hilbertson A (1999) Changes in the regional and compartmental distribution of FosB- and JunB-like immunoreactivity induced in the dopamine-denervated rat striatum by acute or chronic L-DOPA treatment. Neuroscience 94:515-527. CrossRef Medline

Cerovic M, Bagetta V, Pendolino V, Ghiglieri V, Fasano S, Morella I, Hardingham N, Heuer A, Papale A, Marchisella F, Giampà C, Calabresi P, Picconi B, Brambilla R (2014) Derangement of Ras-guanine nucleotide-releasing factor 1 (Ras-GRF1) and extracellular signal-regulated kinase (ERK) dependent striatal plasticity in L-DOPA-induced dyskinesia. Biol Psychiatry. Advance online publication. doi:10.1016/j.biopsych.2014.04.002. CrossRef Medline

Chang MC, Park JM, Pelkey KA, Grabenstatter HL, Xu D, Linden DJ, Sutula TP, McBain CJ, Worley PF (2010) Narp regulates homeostatic scaling of excitatory synapses on parvalbumin-expressing interneurons. Nat Neurosci 13:1090-1097. CrossRef Medline

Cho RW, Park JM, Wolff SB, Xu D, Hopf C, Kim JA, Reddy RC, Petralia RS, Perin MS, Linden DJ, Worley PF (2008) mGluR1/5-dependent longterm depression requires the regulated ectodomain cleavage of neuronal pentraxin NPR by TACE. Neuron 57:858-871. CrossRef Medline

Corvol JC, Muriel MP, Valjent E, Féger J, Hanoun N, Girault JA, Hirsch EC, Hervé D (2004) Persistent increase in olfactory type G-protein alpha subunit levels may underlie D1 receptor functional hypersensitivity in Parkinson disease. J Neurosci 24:7007-7014. CrossRef Medline

Darmopil S, Muñetón-Gómez VC, de Ceballos ML, Bernson M, Moratalla R (2008) Tyrosine hydroxylase cells appearing in the mouse striatum after 
dopamine denervation are likely to be projection neurones regulated by L-DOPA. Eur J Neurosci 27:580-592. CrossRef Medline

Darmopil S, Martín AB, De Diego IR, Ares S, Moratalla R (2009) Genetic inactivation of dopamine D1 but not D2 receptors inhibits L-DOPAinduced dyskinesia and histone activation. Biol Psychiatry 66:603-613. CrossRef Medline

Ding Y, Won L, Britt JP, Lim SA, McGehee DS, Kang UJ (2011) Enhanced striatal cholinergic neuronal activity mediates L-DOPA-induced dyskinesia in parkinsonian mice. Proc Natl Acad Sci U S A 108:840-845. CrossRef Medline

During MJ, Young D, Baer K, Lawlor P, Klugmann M (2003) Development and optimization of adeno-asssociated virus vector transfer into the central nervous system. Methods Mol Med 76:221-236. Medline

Duvoisin RC (1974) Variations in the "on-off" phenomenon. Adv Neurol 5:339-340. Medline

El Atifi-Borel M, Buggia-Prevot V, Platet N, Benabid AL, Berger F, SgambatoFaure V (2009) De novo and long-term l-Dopa induce both common and distinct striatal gene profiles in the hemiparkinsonian rat. Neurobiol Dis 34:340-350. CrossRef Medline

Fasano S, Bezard E, D’Antoni A, Francardo V, Indrigo M, Qin L, Doveró S, Cerovic M, Cenci MA, Brambilla R (2010) Inhibition of Ras-guanine nucleotide-releasing factor 1 (Ras-GRF1) signaling in the striatum reverts motor symptoms associated with L-DOPA-induced dyskinesia. Proc Natl Acad Sci U S A 107:21824-21829. CrossRef Medline

Francardo V, Recchia A, Popovic N, Andersson D, Nissbrandt H, Cenci MA (2011) Impact of the lesion procedure on the profiles of motor impairment and molecular responsiveness to L-DOPA in the 6-hydroxydopamine mouse model of Parkinson's disease. Neurobiol Dis 42:327-340. CrossRef Medline

Gerfen CR, Engber TM, Mahan LC, Susel Z, Chase TN, Monsma FJ Jr, Sibley DR (1990) D1 and D2 dopamine receptor-regulated gene expression of striatonigral and striatopallidal neurons. Science 250:1429-1432. CrossRef Medline

Gerfen CR, Miyachi S, Paletzki R, Brown P (2002) D1 dopamine receptor supersensitivity in the dopamine-depleted striatum results from a switch in the regulation of ERK1/2/MAP kinase. J Neurosci 22:5042-5054. Medline

Gerfen CR, Paletzki R, Worley P (2008) Differences between dorsal and ventral striatum in Drdla dopamine receptor coupling of dopamine- and cAMP-regulated phosphoprotein-32 to activation of extracellular signalregulated kinase. J Neurosci 28:7113-7120. CrossRef Medline

Green CB, Douris N, Kojima S, Strayer CA, Fogerty J, Lourim D, Keller SR, Besharse JC (2007) Nocturnin, a circadian deadenylase, confers resistance to hepatic steatosis and diet-induced obesity. Proc Natl Acad Sci U S A 104:9888-9893. CrossRef Medline

Harvey KF, Kumar S (1999) Nedd4-like proteins: an emerging family of ubiquitin-protein ligases implicated in diverse cellular functions. Trends Cell Biol 9:166-169. CrossRef Medline

Heiman M, Heilbut A, Francardo V, Kulicke R, Fenster RJ, Kolaczyk ED, Mesirov JP, Surmeier DJ, Cenci MA, Greengard P (2014) Molecular adaptations of striatal spiny projection neurons during levodopa-induced dyskinesia. Proc Natl Acad Sci U S A 111:4578-4583. CrossRef Medline

Hervé D, Lévi-Strauss M, Marey-Semper I, Verney C, Tassin JP, Glowinski J, Girault JA (1993) G(olf) and Gs in rat basal ganglia: possible involvement of $\mathrm{G}$ (olf) in the coupling of dopamine D1 receptor with adenylyl cyclase. J Neurosci 13:2237-2248. Medline

Huang da W, Sherman BT, Lempicki RA (2009a) Systematic and integrative analysis of large gene lists using DAVID Bioinformatics Resources. Nat Protoc 4:44-57. Medline

Huang da W, Sherman BT, Lempicki RA (2009b) Bioinformatics enrichment tools: paths toward the comprehensive functional analysis of large gene lists. Nucleic Acids Res 37:1-13. CrossRef Medline

Huot P, Lévesque M, Parent A (2007) The fate of striatal dopaminergic neurons in Parkinson's disease and Huntington's chorea. Brain 130:222232. CrossRef Medline

Jenner P (2008) Molecular mechanisms of L-DOPA-induced dyskinesia. Nat Rev Neurosci 9:665-677. CrossRef Medline

Kobylecki C, Cenci MA, Crossman AR, Ravenscroft P (2010) Calciumpermeable AMPA receptors are involved in the induction and expression of 1-DOPA-induced dyskinesia in Parkinson's disease. J Neurochem 114: 499-511. CrossRef Medline

Kreitzer AC, Malenka RC (2007) Endocannabinoid-mediated rescue of stri- atal LTD and motor deficits in Parkinson's disease models. Nature 445: 643-647. CrossRef Medline

Lebel M, Chagniel L, Bureau G, Cyr M (2010) Striatal inhibition of PKA prevents levodopa-induced behavioural and molecular changes in the hemiparkinsonian rat. Neurobiol Dis 38:59-67. CrossRef Medline

Lindgren HS, Ohlin KE, Cenci MA (2009) Differential involvement of D1 and D2 dopamine receptors in L-DOPA-induced angiogenic activity in a rat model of Parkinson's disease. Neuropsychopharmacology 34:24772488. CrossRef Medline

Lundblad M, Andersson M, Winkler C, Kirik D, Wierup N, Cenci MA (2002) Pharmacological validation of behavioural measures of akinesia and dyskinesia in a rat model of Parkinson's disease. Eur J Neurosci 15:120-132. CrossRef Medline

Lundblad M, Picconi B, Lindgren H, Cenci MA (2004) A model of L-DOPA-induced dyskinesia in 6-hydroxydopamine lesioned mice: relation to motor and cellular parameters of nigrostriatal function. Neurobiol Dis 16:110-123. CrossRef Medline

Lundblad M, Usiello A, Carta M, Håkansson K, Fisone G, Cenci MA (2005) Pharmacological validation of a mouse model of l-DOPA-induced dyskinesia. Exp Neurol 194:66-75. CrossRef Medline

Meurers BH, Dziewczapolski G, Shi T, Bittner A, Kamme F, Shults CW (2009) Dopamine depletion induces distinct compensatory gene expression changes in DARPP-32 signal transduction cascades of striatonigral and striatopallidal neurons. J Neurosci 29:6828-6839. CrossRef Medline

Moran LB, Hickey L, Michael GJ, Derkacs M, Christian LM, Kalaitzakis ME, Pearce RK, Graeber MB (2008) Neuronal pentraxin II is highly upregulated in Parkinson's disease and a novel component of Lewy bodies. Acta Neuropathol 115:471-478. CrossRef Medline

Nadjar A, Gerfen CR, Bezard E (2009) Priming for L-DOPA-induced dyskinesia in Parkinson's disease: a feature inherent to the treatment or the disease? Prog Neurobiol 87:1-9. CrossRef Medline

Obeso JA, Rodriguez-Oroz MC, Rodriguez M, DeLong MR, Olanow CW (2000) Pathophysiology of levodopa-induced dyskinesias in Parkinson's disease: problems with the current model. Ann Neurol 47:S22-S32; discussion S32-S34. Medline

O’Brien R, Xu D, Mi R, Tang X, Hopf C, Worley P (2002) Synaptically targeted Narp plays an essential role in the aggregation of AMPA receptors at excitatory synapses in cultured spinal neurons. J Neurosci 22:44874498. Medline

Pacchioni AM, Kalivas PW (2009a) The role of AMPAR trafficking mediated by neuronal pentraxins in cocaine-induced neuroadaptations. Mol Cell Pharmacol 1:183-192. CrossRef Medline

Pacchioni AM, Vallone J, Worley PF, Kalivas PW (2009b) Neuronal pentraxins modulate cocaine-induced neuroadaptations. J Pharmacol Exp Ther 328:183-192. CrossRef Medline

Pavón N, Martín AB, Mendialdua A, Moratalla R (2006) ERK phosphorylation and FosB expression are associated with L-DOPA-induced dyskinesia in hemiparkinsonian mice. Biol Psychiatry 59:64-74. CrossRef Medline

Paxinos G, Franklin KBJ (2001) The mouse brain in stereotaxic coordinates, Ed 2. San Diego: Academic.

Picconi B, Centonze D, Håkansson K, Bernardi G, Greengard P, Fisone G, Cenci MA, Calabresi P (2003) Loss of bidirectional striatal synaptic plasticity in L-DOPA-induced dyskinesia. Nat Neurosci 6:501-506. CrossRef Medline

Putterman DB, Munhall AC, Kozell LB, Belknap JK, Johnson SW (2007) Evaluation of levodopa dose and magnitude of dopamine depletion as risk factors for levodopa-induced dyskinesia in a rat model of Parkinson's disease. J Pharmacol Exp Ther 323:277-284. CrossRef Medline

Rangel-Barajas C, Silva I, Lopéz-Santiago LM, Aceves J, Erlij D, Florán B (2011) L-DOPA-induced dyskinesia in hemiparkinsonian rats is associated with up-regulation of adenylyl cyclase type V/VI and increased GABA release in the substantia nigra reticulata. Neurobiol Dis 41:51-61. CrossRef Medline

Saeed AI, Sharov V, White J, Li J, Liang W, Bhagabati N, Braisted J, Klapa M, Currier T, Thiagarajan M, Sturn A, Snuffin M, Rezantsev A, Popov D, Ryltsov A, Kostukovich E, Borisovsky I, Liu Z, Vinsavich A, Trush V, Quackenbush J (2003) TM4: a free, open-source system for microarray data management and analysis. Biotechniques 34:374-378. Medline

Santini E, Valjent E, Usiello A, Carta M, Borgkvist A, Girault JA, Hervé D, Greengard P, Fisone G (2007) Critical involvement of cAMP/DARPP-32 and extracellular signal-regulated protein kinase signaling in L-DOPA-induced dyskinesia. J Neurosci 27:6995-7005. CrossRef Medline 
Santini E, Alcacer C, Cacciatore S, Heiman M, Hervé D, Greengard P, Girault JA, Valjent E, Fisone G (2009a) L-DOPA activates ERK signaling and phosphorylates histone $\mathrm{H} 3$ in the striatonigral medium spiny neurons of hemiparkinsonian mice. J Neurochem 108:621-633. CrossRef Medline

Santini E, Heiman M, Greengard P, Valjent E, Fisone G (2009b) Inhibition of mTOR signaling in Parkinson's disease prevents L-DOPA-induced dyskinesia. Sci Signal 2:ra36. CrossRef Medline

Santini E, Sgambato-Faure V, Li Q, Savasta M, Dovero S, Fisone G, Bezard E (2010) Distinct changes in cAMP and extracellular signal-regulated protein kinase signalling in L-DOPA-induced dyskinesia. PLoS One 5:e12322. CrossRef Medline

Santini E, Feyder M, Gangarossa G, Bateup HS, Greengard P, Fisone G (2012) Dopamine-and cAMP-regulated phosphoprotein of 32-kDa (DARPP32)-dependent activation of extracellular signal-regulated kinase (ERK) and mammalian target of rapamycin complex 1 (mTORC1) signaling in experimental parkinsonism. J Biol Chem 287:27806-27812. CrossRef Medline

Schuster S, Nadjar A, Guo JT, Li Q, Ittrich C, Hengerer B, Bezard E (2008) The 3-hydroxy-3-methylglutaryl-CoA reductase inhibitor lovastatin reduces severity of L-DOPA-induced abnormal involuntary movements in experimental Parkinson's disease. J Neurosci 28:4311-4316. CrossRef Medline

Shen W, Flajolet M, Greengard P, Surmeier DJ (2008) Dichotomous dopa- minergic control of striatal synaptic plasticity. Science 321:848-851. CrossRef Medline

Tashiro Y, Sugimoto T, Hattori T, Uemura Y, Nagatsu I, Kikuchi H, Mizuno N (1989) Tyrosine hydroxylase-like immunoreactive neurons in the striatum of the rat. Neurosci Lett 97:6-10. CrossRef Medline

Tsui CC, Copeland NG, Gilbert DJ, Jenkins NA, Barnes C, Worley PF (1996) Narp, a novel member of the pentraxin family, promotes neurite outgrowth and is dynamically regulated by neuronal activity. J Neurosci 16: 2463-2478. Medline

Valjent E, Pascoli V, Svenningsson P, Paul S, Enslen H, Corvol JC, Stipanovich A, Caboche J, Lombroso PJ, Nairn AC, Greengard P, Hervé D, Girault JA (2005) Regulation of a protein phosphatase cascade allows convergent dopamine and glutamate signals to activate ERK in the striatum. Proc Natl Acad Sci U S A 102:491-496. CrossRef Medline

Westin JE, Vercammen L, Strome EM, Konradi C, Cenci MA (2007) Spatiotemporal pattern of striatal ERK1/2 phosphorylation in a rat model of L-DOPA-induced dyskinesia and the role of dopamine D1 receptors. Biol Psychiatry 62:800-810. CrossRef Medline

Xu D, Hopf C, Reddy R, Cho RW, Guo L, Lanahan A, Petralia RS, Wenthold RJ, O’Brien RJ, Worley P (2003) Narp and NP1 form heterocomplexes that function in developmental and activity-dependent synaptic plasticity. Neuron 39:513-528. Medline 